\title{
Predicting sheetwash and rill erosion over the Australian continent
}

\author{
Hua Lu ${ }^{\mathrm{A}, \mathrm{B}}$, Ian P. Prosser ${ }^{\mathrm{A}}$, Chris J. Moran ${ }^{\mathrm{A}}$, John C. Gallant ${ }^{\mathrm{A}}$, Graeme Priestley $^{\mathrm{A}}$, \\ and Janelle G. Stevenson ${ }^{\mathrm{A}}$
}

${ }^{\mathrm{A} C S I R O ~ L a n d ~ a n d ~ W a t e r, ~ G P O ~ B o x ~ 1666, ~ C a n b e r r a, ~ A C T ~ 2601, ~ A u s t r a l i a . ~}$

${ }^{\mathrm{B} C}$ orresponding author; email: hua.lu@csiro.au

\begin{abstract}
Soil erosion is a major environmental issue in Australia. It reduces land productivity and has off-site effects of decreased water quality. Broad-scale spatially distributed soil erosion estimation is essential for prioritising erosion control programs and as a component of broader assessments of natural resource condition. This paper describes spatial modelling methods and results that predict sheetwash and rill erosion over the Australian continent using the revised universal soil loss equation (RUSLE) and spatial data layers for each of the contributing environmental factors. The RUSLE has been used before in this way but here we advance the quality of estimation. We use time series of remote sensing imagery and daily rainfall to incorporate the effects of seasonally varying cover and rainfall intensity, and use new digital maps of soil and terrain properties. The results are compared with a compilation of Australian erosion plot data, revealing an acceptable consistency between predictions and observations. The modelling results show that: (1) the northern part of Australia has greater erosion potential than the south; (2) erosion potential differs significantly between summer and winter; (3) the average erosion rate is $4.1 \mathrm{t} / \mathrm{ha}$.year over the continent and about $2.9 \times 10^{9}$ tonnes of soil is moved annually which represents $3.9 \%$ of global soil erosion from $5 \%$ of world land area; and (4) the erosion rate has increased from 4 to 33 times on average for agricultural lands compared with most natural vegetated lands.
\end{abstract}

Additional keywords: soil erosion, prediction, RUSLE, Australia.

\section{Introduction}

Soil erosion is a natural process that contributes to the evolution of the land surface. It is governed by topography, climate, soil, vegetation cover, and land use and management factors through mechanisms including particle detachment by raindrop impact, hydrology, flow hydraulics, and other processes. Across Australia, soil erosion varies spatially and temporally by several orders of magnitude due to changes in those factors (Edwards 1993; Wasson et al. 1996). The ability to estimate erosion rate at national scale is significant for 3 reasons. Firstly, soil erosion has a range of environmental impacts, including loss of organic matter and nutrients, reduction of crop productivity, and downstream water quality degradation (Newcombe and MacDonald 1991). The integrated impacts are often revealed and of importance at catchment or even broader scales. Secondly, effective control of soil erosion is a critical component of natural resource management when the aim is to achieve sustainable agriculture and acceptable ecosystem integrity (Pimentel et al. 1995; Rutherfurd et al. 1998). With limited resources, national scale erosion maps are useful for guiding investment prioritisation in effective remediation programs. Thirdly, to aid estimations of soil erosion contributions and their impacts at global scale, the effects of changes in climatic conditions, vegetation, and land use on soil erosion rates need to be assessed at regional to continental scales (Pimentel et al. 1995).

Considerable knowledge of processes involved in soil erosion has been gained in a variety of ways, including fundamental theoretical developments, small-scale experimentation, and numerical simulation. The resulting process-based models are often 
not suited to broad-scale problems, for a number of reasons: (1) they require too many parameters which are generally too expensive or even impossible to determine reliably; (2) the input data, such as hydraulic resistance, infiltration rate, and soil properties including particle size distributions, are not commonly available over large spatial extents; (3) there is large sub-pixel variability in microphysical parameters and soil properties which cannot be resolved by the coarse resolution environmental data available at national scale; and (4) we have insufficient knowledge to be certain of the importance of non-linear interaction between parameters in process-based models developed to represent local processes when they are linearly scaled up to be applied over large domains. Some aspects omitted by small-scale investigations could be significant at broad scales.

A commonly used erosion model is the universal soil loss equation (USLE) (Wischmeier and Smith 1978) or the revised USLE (RUSLE) (Renard et al. 1997). The USLE/RUSLE was statistically derived from a large empirical database generated from plot experiments in the United States. It estimates long-term average annual soil loss rate using a factor-based approach with rainfall, soil, topography, and land cover and management as inputs. Originally it was developed for plot scale soil conservation purposes but has also gained acceptance in broad-scale applications, for the reasons: (1) it distils soil erosion into a set of measurable primary environmental controls and therefore facilitates the input data accessibility over large regions; (2) it provides a consistent basis for revealing the major responses of soil erosion to the changes in environmental conditions, climate, land use and management practices; and (3) it has a simple mathematical form facilitating the handling of large data sets and is cost-effective in operation using GIS.

In Australia, field measurements of soil erosion are sparse. Large areas with diverse environments are poorly covered (Edwards 1993; Wasson et al.1996; Rosewell 1997). The derived statistical relationships from individual erosion measurements are confined to their local conditions and provide a limited basis for extrapolating to other areas. Therefore, care must be exercised in using those measurements to extrapolate across the nation. However, good agreement has been found between some field measurements and the predictions of the USLE. Freebairn et al. (1989) tested 3 USLE-based soil erosion models using field data collected from the Darling Downs area in Queensland. They found all 3 models explained $>80 \%$ of the variance in measured soil loss. The Australia version of RUSLE, SOILOSS (Rosewell 1993) was derived using the field measurements from erosion plots at several research stations in New South Wales (Rosewell 1986; Edwards 1987). In SOILOSS, the relationships for some original USLE/RUSLE factors, such as cover management (Rosewell 1993), soil erodibility (Loch and Rosewell 1992; Loch et al. 1998), and rainfall erosivity (Yu and Rosewell 1996) were modified. Further, the plot data from other States were incorporated (Freebairn 1982; Freebairn and Wockner 1986). Recent sediment yield measurements from small farm dams found that both RUSLE and SOILOSS made reliable predictions in 2 areas out of 3 near Sydney (Erskine et al. 2002, 2003; Mahmoudzadeh et al. 2002). Excellent correlations were found for sandstone catchments (above $80 \%$, Erskine et al. 2002, 2003), but poor correlations for granite catchments (31\%, Mahmoudzadeh et al. 2002). It is worth pointing out that the broad-scale applications of simple empirical models, such as USLE/RUSLE/SOILOSS, can be inaccurate for making farm-scale predictions because some of the local variability is smoothed or not incorporated. However, at national scale, where there are orders of magnitude of variation in erosion rates and where it is the broad patterns that are of concern, the influences of these local descriptors are outweighed by the broad-scale variations inherent in the landscape, climate, and vegetation cover. 
Previous assessments of soil erosion across Australia include one for the national State of the Environment Report (Rosewell 1997), and a national reconnaissance erosion survey using Caesium-137 (Loughran and Elliott 1996; McFarlane et al. 2000) conducted as part of the National Soil Conservation Program. Other broad-scale assessments include the NSW Land Degradation Survey (Graham 1988) based upon aerial photograph interpretation. Considerably more detailed, consistent, and reliable spatial data have become available in Australia over the last 5 years, enabling us to make a new assessment of nation-wide soil erosion based on USLE/RUSLE/SOILOSS. In the late 1990s, Australia launched the National Land and Water Resources Audit (NLWRA) (http://www.nlwra. gov.au/) to assess the condition of its land and water resources. The continent-wide assessment of sheetwash and rill erosion, which we report in this paper, was conducted as part of a broader assessment of the conditions of Australian agricultural land (NLWRA 2001).

The aim of this study was to provide an up-to-date map of long-term average annual sheetwash and rill erosion with its monthly distribution across Australia. We included new national datasets on rainfall, soils, vegetation cover, land use, and topography. We incorporated seasonal rainfall erosivity and vegetation cover, which Rosewell (1997) suggested were needed for a more accurate replica of the observed continental pattern of erosion. Using rule-based approaches, we scaled slope gradient and slope length to the resolution suitable for modelling erosion. We separated the erosion patterns produced by natural environmental variation from those due to present land use to assist assessment of the impacts of land use on erosion rate.

\section{Methods}

The USLE/RUSLE/SOILOSS calculate mean annual soil loss $(Y$, t/ha.year $)$ as a product of 6 factors: rainfall erosivity $(R)$, soil erodibility $(K)$, hillslope length $(L)$, hillslope gradient $(S)$, ground cover $(C)$, and supporting practice $(P)$ :

$$
Y=R K L S C P
$$

The approach that we used to implement Eqn 1 across Australia is summarised in Fig. 1. The primary differences between SOILOSS and USLE/RUSLE are the estimations of $C$ and $K$ factors. $C$ and $K$ factors in SOILOSS were calibrated using field measurements from New South Wales (Edwards 1987) and some laboratory measurements (Loch and Rosewell 1992). In general, SOILOSS produces lower $C$ values compared with USLE/RUSLE, which is consistent with measurements from the Darling Downs area (Freebairn et al. 1996). The modification by Loch and Rosewell (1992) improved the estimation of the $K$-factor for Australian soils, especially for heavy clay soils. Recent studies of Erskine et al. (2002, 2003) and Mahmoudzadeh et al. (2002) confirmed that for Australian conditions, SOILOSS often performs better than RUSLE or USLE. For this reason, SOILOSS was used in this study.

Spatially distributed applications of Eqn 1 often use the mean annual values for rainfall erosivity and the cover factor to calculate mean annual sheetwash and rill erosion (Rosewell 1997). This neglects important seasonal patterns of rainfall erosivity and cover. Problematic for the annual application of the RUSLE is the pronounced wet-dry precipitation regime in the Australian tropics and Mediterranean climate areas such as south Western Australia. The coincidence of erosive rains with low cover in some regions is a strong control on the mean annual rates. To adequately represent the erosive potential of rainfall for each temporally distinctive period, we applied the RUSLE on a monthly average basis by calculating appropriate erosivity and cover factors for each month.

R-factor

The $R$-factor and its monthly distributions were calculated using a daily rainfall erosivity model (Yu and Rosewell 1996) that predicts $R$ on the basis of an empirical relationship between $R$-factor calculated using pluviograph rainfall data and daily rainfall amount. The modelled $R$-factor values agree with those estimated using high temporal resolution rainfall data for 132 sites covering a wide range of climates across 


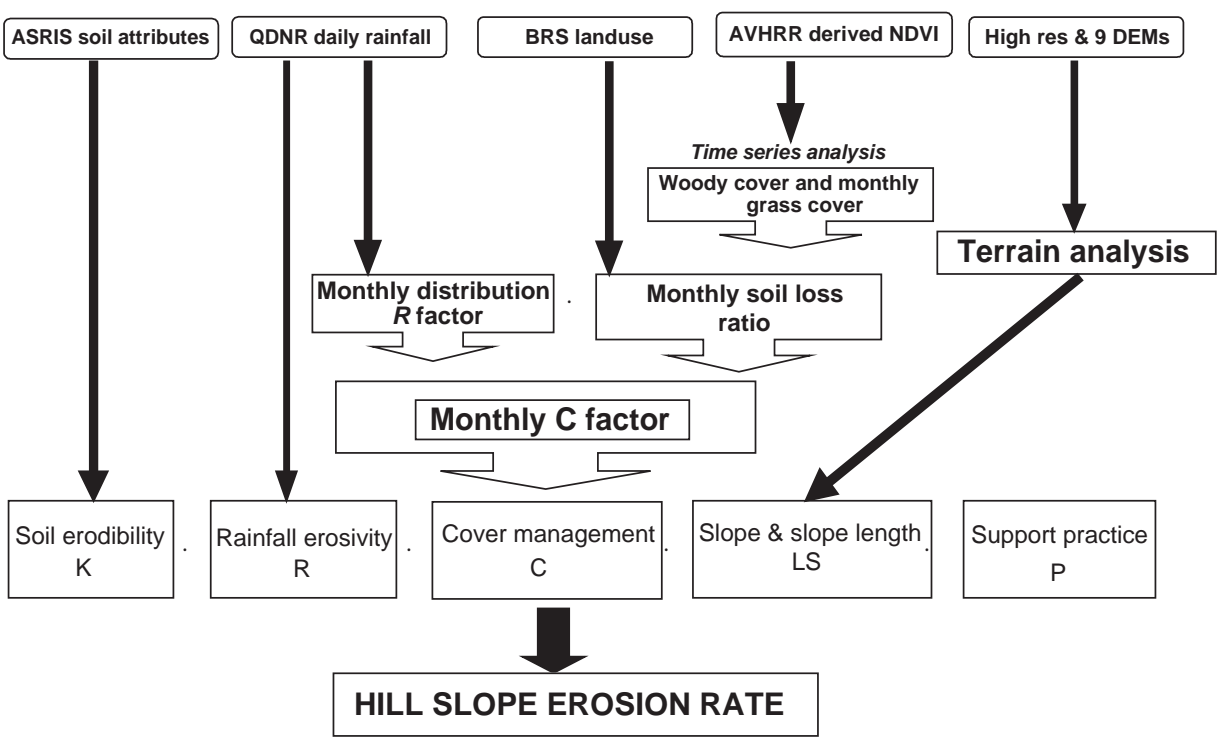

Fig. 1. Flowchart of inputs, middle components, and output for RUSLE as applied in this study.

Australia ( $\mathrm{Lu}$ and $\mathrm{Yu}$ 2002). The coefficient of efficiency is 0.94 for the $R$-factor and the error of monthly distribution is around $2.5 \%$. The model was applied to 20 years $(1980-2000)$ of daily rainfall interpolated from station measurements to a grid of $0.05^{\circ}$ resolution (Jeffrey et al. 2001). The resulting annual $R$-factor and its monthly distributions at grid resolution of $0.05^{\circ}$ were reported by $\mathrm{Lu}$ and $\mathrm{Yu}$ (2002).

K-factor

The USLE nomograph (Wischmeier et al. 1971) estimates erodibility $(K)$ as:

$$
K=2.77 \times 10^{-7} \times M^{1.14}\left(12-2 O_{c}\right)+4.28 \times 10^{-3}\left(S_{s}-2\right)+3.29 \times 10^{-3}\left(R_{p r}-3\right)
$$

where $\mathrm{M}=(\%$ silt $+\%$ very fine sand $)(100-\%$ clay $), O_{c}$ is the organic matter content in percentage, $S_{s}$ is soil structure code, and $R_{p r}$ is the soil permeability rating. Loch and Rosewell (1992) and Loch et al. (1998) suggested that replacing $M$ by $100 \mathrm{P}_{125}$ and including the wet sediment density improve the prediction of $K$ values, especially for clay soil in Australia, where $100 \mathrm{P}_{125}$ is the percentage of particles $<125 \mu \mathrm{m}$ at the soil surface following wetting by rain (minimum dispersing of natural soil aggregates). The modified nomograph of Loch and Rosewell (1992) was expressed as:

$$
K=\left[2.77 \times 10^{-7} \times\left(100 P_{125}\right)^{1.14}\left(12-2 O_{c}\right)+4.28 \times 10^{-3}\left(S_{s}-2\right)+3.29 \times 10^{-3}\left(R_{p r}-3\right)\right] /\left(d_{s}-1\right)
$$

where $d_{s}$ is the wet sediment density which Loch and Rosewell (1992) suggested to be estimated by:

$$
d_{s}=1.462+0.048(1.03259)^{\% \text { sand }}
$$

where $\%$ sand is percentage sand with particle $>20 \mu \mathrm{m}$

The new soil information data sets derived by Australian Soil Resources Information Systems (ASRIS) enable us to estimate erodibility $(K)$ based on the modified USLE nomograph (Eqns 3 and 4 ) of Loch and Rosewell (1992). In ASRIS, a range of soil attributes, including soil texture, hydraulic conductivity, and carbon context were derived by combing digitised land systems maps and soil surveys and linked to look-up tables listing soil type and corresponding attribute values (McKenzie et al. 2000; Carlile et al. 2001b). Texture classes used in soil attribute look-up tables were converted to average percentage sand, silt and clay values using fuzzy $k$-means (De Gruijter and McBratney 1988; Carlile et al. 2001a). 


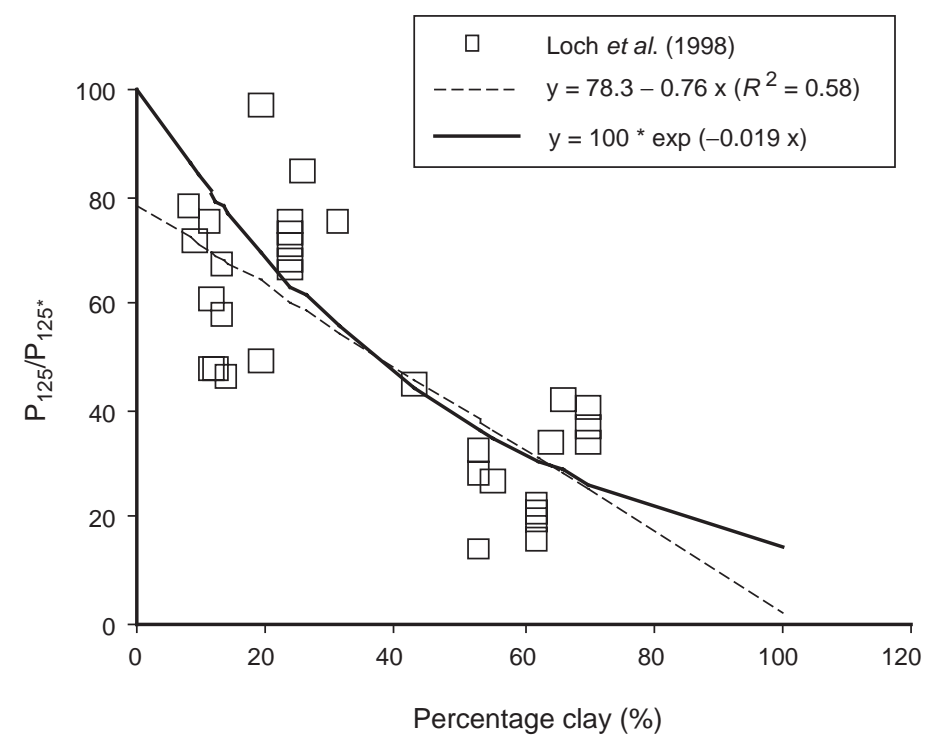

Fig. 2. Effect of soil clay content (\%clay) on the ratio between the percentage particles $<125 \mu \mathrm{m}$ presented in rainfall-wet soil $\left(100 \mathrm{P}_{125}\right)$ and the percentage fully dispersed particles $<125 \mu \mathrm{m}\left(100 \mathrm{P}_{125}^{*}\right)$. Measurements of Loch et al. (1998) and two fitted lines are shown.

Most of the input parameters required by Eqns 3 and 4 can be directly estimated from the ASRIS database, except $100 \mathrm{P}_{125} \cdot 100 \mathrm{P}_{125}$ is a measure of water-stable aggregation of soil, which is primarily affected by soil properties, such as clay content. From ASRIS, we had fully dispersed particle size distributions including percentage particles $<125 \mu \mathrm{m}$ (we call it $100 \mathrm{P}_{125}^{*}$ hereafter). $100 \mathrm{P}_{125}^{*}$ was estimated by adding percentage clay $(<2 \mu \mathrm{m})$, percentage silt $(2-20 \mu \mathrm{m})$ and percentage fine sand $(20-125 \mu \mathrm{m})$ (estimated by linear interpolation of percentage sand $(20-2000 \mu \mathrm{m})$ ). With limited measurements, Loch et al. (1998) showed that the ratio of $100 \mathrm{P}_{125} / 100 \mathrm{P}_{125}^{*}$ decreases with increase in \%clay. Figure 2 shows Loch et al. (1998) data and 2 fitted relationships with one linear and one non-linear. The non-linear relationship $100 \mathrm{P}_{125} / 100 \mathrm{P}_{125}^{*}=100 \exp (-0.018 \%$ clay $)$ is used in this study to relate $100 \mathrm{P}_{125}$ to percentage clay (\%clay) and $100 \mathrm{P}_{125}^{*}$ as it is more likely that soils with zero per cent of clay tend to become fully dispersed under rainfall wet conditions and $100 \mathrm{P}_{125}$ is close to $100 \mathrm{P}_{125}^{*} . O_{c}$ was calculated as $1.72 O_{\text {carbon }}$, where $O_{\text {carbon }}$ is percentage soil organic carbon (Rosewell 1993). $O_{\text {carbon }}$ was estimated using the ASRIS point database, climatic and elevation information through statistical modelling (Henderson et al. 2001). The soil permeability class surface was constructed using the A-horizon hydraulic conductivity surface produced by ASRIS and the same soil permeability classes recommended by USLE (Wischmeier and Smith 1978). As there is not sufficient information to estimate spatially distributed values of the soil structure code $S_{s}$, a uniformed value of $S_{s}=3$ (assuming the major soils have aggregates with diameter of medium or coarse granular $2-10 \mathrm{~mm}$ ) is used across the continent.

It is worth noting that the $K$-factor derived in this study is based mainly on particle size distributions, soil carbon content, and soil permeability rates. In reality, values of $K$-factor can be significantly altered by management (governed by the degree of soil disturbance, aggregation, organic matter content and hydraulic conductivity) and soil chemical content (Loch and Rosewell 1992). The deviations from the norm due to atypical management were not considered in this study and can only be dealt with at a much finer scale where high quality information is available.

\section{C-factor}

The most critical part of this study is estimation of the cover factor ( $C$-factor) using remote sensing data and land use information. For land uses except cropping lands, the $C$-factor is controlled mainly by vegetation cover. For cropping lands, in addition to vegetation cover, management practices, such as crop rotation, stubble incorporation, and tillage, are also important. Those factors account for the effects of the 
seasonal interaction between erosive rainfall and ground cover, the amount of dead vegetation left for soil protection and the frequency of soil disturbance by cultivation (Rosewell 1993; Renard et al. 1997).

We used 3 major steps to estimate the $C$-factor. Firstly, the monthly spatial distribution of the fraction of green vegetation cover was estimated using time series decomposition of remotely sensed data (Lu et al. $2003 \mathrm{~b}$ ). The time series decomposition was carried out using 13-years (1981-94) of NOAA/NASA Pathfinder GAC 8-km Advanced Very High Resolution Radiometer (AVHRR) 10-day maximum composite normalised difference vegetation index (NDVI) data. This novel decomposition method combined forward and inverse approaches and is formally consistent with fundamental linearity requirements and is capable of rejecting contaminated NDVI signals. Secondly, monthly soil loss ratios (SLRs) were calculated using the fraction of green vegetation cover with consideration of the different land use groups suggested in RUSLE (Renard et al. 1997) and SOILOSS (Rosewell 1993). The SLR is the ratio of soil loss under the soil surface conditions in question to that under continuously bare soil for a given time period. The land use groups were derived from a combination of the 1-km resolution national land use map based on 1997 land use information (BRS 2002) and some locally available high resolution land use data mainly for the eastern part of the country. Finally, monthly $C$-factors were estimated by weighting monthly SLRs using the monthly $R$-factor distributions as the weighting factors (Renard et al. 1997). The annual $C$-factor is obtained by summing the 12-monthly averaged $C$-factors.

The estimation of SLR involves the following assumptions for cropping lands except for sugar cane. A single crop rotation is applied with a half-year growth period and a half-year of fallow. Harvesting is assumed to occur 2 months after the month with peak green cover and sowing starts 3 months before the month with peak green cover. The month with peak green cover is determined from average monthly herbaceous cover derived from the remote sensing time series ( $\mathrm{Lu}$ et al. 2003b). The surface residue and stubble root mass after harvest were both estimated as $50 \%$ of the equivalent green cover just before harvest. Conventional tillage is applied across the croplands with 3 tillage operations during the fallowing period. The first tillage pass occurs 2 months after harvest with 2-month intervals between the following passes. About $20 \%$ of surface residues are incorporated into the soil during each pass. Both surface and in-soil residues decay linearly to zero from harvest to harvest in a 1-year cycle. All the above assumptions were made according to the averaged values for a given land use group suggested by the literature (Rosewell 1993; Freebairn et al. 1996). With these assumptions, the estimation of monthly SLR for cropping lands follows RUSLE and SOILOSS. Areas with double cropping (winter and summer) were identified from the monthly average herbaceous cover (Lu et al. 2003b). For those areas, the annual $C$-factor is modelled by assuming half the pixel was used for winter cropping and another half was used for summer cropping and the average of the $C$-factor is applied over the total area.

For canelands, an average 4-year cultivation cycle was assumed with 1-year conventional cultivation described above and no-tillage in the following 3 years. Harvest occurs each year with burning after first year harvest (followed by cultivations) and green cane trash blanketing after harvest during no-tillage years. The average cane growth was set to 12 months and harvest was assumed to occur in October with no fallow between growth periods. All these settings were guided by the recommendations of the Queensland Sugar Corporation (QSC 1997).

For native grass and woodlands, the monthly SLR was calculated as the product of sub-factors following Rosewell (1997):

$$
\begin{aligned}
& S L R=f_{c p} * f_{s f} \\
& f_{c p}=1-\left(C_{w} / 100\right) * \exp (-0.328 h) \\
& f_{S f}=\exp \left(0.8+0.04 C_{s}+0.0005 C_{s}^{2}+0.000005 C_{s}^{3}\right)
\end{aligned}
$$

where $f_{c p}$ and $f_{s f}$ are sub-factors for canopy and surface cover respectively, cover, $C_{w}, C_{s}$ and $h$ are the canopy cover $(\%)$, surface cover (including herbaceous vegetation and litter) (\%), and canopy height (in metres) respectively. The average litter cover was assumed to equal half the annual peak herbaceous cover estimated using remote sensing data ( $\mathrm{Lu}$ et al. 2003b). No attempt was made to include rock cover in the assessment of surface cover.

For forest land, the $C$-factor was interpolated between 0.009 and 0.0001 , as suggested in Table D4 of Rosewell (1993), according to the estimated woody cover derived from remotely sensed data. For watercourses (including wetlands and mangroves) and built up areas, the $C$-factor was set to 0.0 and 0.001 respectively, regardless of cover. 
For forest plantations and orchards, we assumed an average 30-year cutting cycle (Croke et al. 1999). For the first 3 years, removing vegetation and disturbing the soil surface due to logging has a major effect on $C$-factor and therefore erosion rate (Croke et al. 1999). The SLR was set to 0.2, 0.1, and 0.05 for the first, second, and third year after harvest, respectively, with equal values for each month. Those values were chosen according to plot measurements. Following initial soil disturbances, vegetation cover becomes well established after 3 years (Croke et al. 1999; Yu et al. 2000; Wallbrink et al. 2002). The monthly SLR values for the other following years were set to those for native vegetation with the same percentage cover for the given month, implying that for established plantations the erosion rate is mainly controlled by natural forces. The long-term averaged monthly SLR values were calculated as the average values over the cutting cycle.

\section{$\mathrm{L}$ and $\mathrm{S}$ factors}

The best available digital elevation model (DEM) for the continental has a resolution of 9" (approx. $250 \mathrm{~m}$ ). Hillslope length and variations in slope gradient are not well represented at that resolution. In this study, this was overcome by using prediction rules to generate the $L$ and $S$ based on measurements of hillslope length and slope from high resolution DEMs. The method is described in detail in Gallant (2001) and is summarised here.

The high resolution DEMs used to measure hillslope length and slope were mostly at 20-50 m resolution, included sites from all states and territories and covered a wide range of geomorphic settings, geologies and climate. 18 DEMs were used covering a total area of approximately $400000 \mathrm{~km}^{2}$.

Slope was calculated within the Arc/Info GIS (ESRI 2003) and then averaged over a circular window of $250 \mathrm{~m}$ radius to correspond with the resolution at which predictions were required.

Hillslope length was measured using a scale-dependent landscape classification algorithm HillLength2 that classifies a DEM point into 1 of 4 classes - top, bottom, hillslope, or indeterminate. This classification is based on a circular window of variable size and has the property that for small windows most of the landscape is classified as hillslopes, while for large windows most of the landscape is classified as indeterminate. Hillslope length corresponds to the window size at which those 2 classifications give equal numbers of points over a defined area (Gallant 2001). This analysis produced mean hillslope length at a grid spacing of $250 \mathrm{~m}$. Areas with very low relief (standard deviation of elevation over a $2-\mathrm{km}$ radius is $<5 \mathrm{~m}$ ) were excluded because there is not sufficient detail to measure hillslope length reliably.

Predictive rules for hillslope length and slope were then derived using the Cubist (Rulequest Research 2001) data mining software. The predictive variables consisted of a number of attributes representing the major factors presumed to control fine scale landform shape: materials, climate, and regional geomorphology. Sixteen variables were used for the prediction: 2 aggregated geology classifications derived from the $1: 2.5 \mathrm{M}$ scale geology map of Australia; a more detailed lithology surface provided by the Bureau of Rural Sciences; the Australian Soil Classification derived from the Atlas of Australian Soils; mean annual rainfall, rainfall seasonality index, and annual moisture index; mean annual temperature, temperature seasonality, and diurnal temperature range; relief, relative elevation, and slope position within land units defined by ridge and stream networks from the 9" DEM; standard deviation of elevation and elevation ranking within a 2-km radius circular window from the 9" DEM; and slope from the 9" DEM. The rules were based on approximately 200000 sample points and a further 60000 sample points were used to test the derived rules.

Cubist produces a set of rules consisting of linear combinations of some predictive variables that are applicable for a given range of values of some predictive variables. The model for hillslope length used all 16 predictive variables in 55 rules giving a correlation coefficient of 0.71 on the test data. The model for slope used 10 variables in 53 rules with a correlation coefficient of 0.87 on the test data.

Maps showing the predictions of hillslope length and slope are included in Gallant (2001). One example of the prediction hillslope length is the following rule that applies in the upper reaches of many river systems in south-eastern Australia:

$$
\begin{aligned}
& \text { if relev }<47 \text { and s.d. }>22 \text { and geol } \notin\{2,8\} \text { and lith } \notin\{1,14,17,18,19\} \\
& \text { then }-h l=20.8-0.37 \text { relev }+0.25 \text { s.d. }+54 \text { pctl }+0.038 \text { tempseas } \\
& +0.012 \text { annrain }+0.00043 \text { rainseas }
\end{aligned}
$$

where relev is relative elevation within topographic land units ( $m$ above lowest point), s.d. is standard deviation of elevation (m), geol is geology class (8 classes), lith is lithology class (22 classes), $h l$ is hillslope 
length, pctl is elevation ranking ( $0-1)$, tempseas is temperature seasonality (multiplied by 1000 , mean $=$ 1644 , s.d. $=399)$, annrain is mean annual rainfall $(\mathrm{mm}$, mean $=603$, s.d. $=379)$, and rainseas is rainfall seasonality (multiplied by 1000 , mean $=41945$, s.d. $=26087$ ). This rule is applicable in the lower parts of the local landscape (low relev) in higher relief areas (high s.d.) and outside the specific geology and lithology classes listed; it predicts that hillslope length increases with increasing relief (s.d.) and with increasing temperature seasonality, annual rainfall, and rainfall seasonality. The relev and pctl terms measure similar properties - height relative to the surrounding terrain, but in different ways so their opposite influences are presumably capturing a relationship that is more complex than a simple increase or decrease in hillslope length with position in the landscape.

There are many rules for both hillslope length and slope, most of which involve more factors than the one shown here. Many of the rules also work in combination with other rules since the conditions under which the rules apply are not mutually exclusive. These factors make a detailed interpretation of the rules very difficult. Since the purpose of generating the rules was spatial prediction and not generating geomorphic understanding this difficulty of interpretation was not considered to be an obstacle to the use of the rules and the value of the model is judged by the validation of the predictive capacity as measured by the correlation with test data.

The $L$ and $S$ factors were calculated from the modelled hillslope length and slope values using the standard RUSLE equations (Renard et al. 1997). For those flat areas where hillslope length cannot be estimated reliably, a fixed value of $L$ equal to 1 is used. This would have limited effect on our final estimations, as erosion rates from flat area are naturally small.

P-Factor

The $P$-factor was not modelled due to a lack of spatial data on existing contour bank locations. Thus, for cropping lands, the estimated soil loss rate reflects erosion potential under current conditions with no soil conservation support practices other than cover management.

\section{Prediction of erosion rate under pre-European conditions}

To better understand the relative impact of land use and management practices on hillsope erosion, the predicted sheetwash and rill erosion needs to be put in the context of erosion under natural vegetation cover. We predicted natural erosion using the same procedure, with a cover factor for native vegetation, keeping the other factors as for the present day. An empirical modelling framework to predict the pre-European settlement (undisturbed) USLE $C$-factor was implemented.

There are 2 basic assumptions of this modelling framework: (I) climate, soil type, geology, and terrain conditions remain unchanged since European settlement; (2) the natural vegetation and soil surface conditions remain similar to pre-settlement condition in areas of limited disturbance. Based on those two assumptions, we sampled the $C$-factor from those areas with limited disturbance, built statistical models using climate, soil, geological and terrain variables as predictor variables and used the models to extrapolate to those areas with substantial disturbance by human intervention, especially agricultural activities such as cropping, grazing, and tree clearing.

The statistical models were constructed using the Cubist data mining tool (Rulequest Research 2001) in a similar way as we used for the predictions of hillslope length and slope (see section $L$ and $S$ Factors). In this study, we reserved a proportion of the sample set to test the model, calculating statistics of model performance for both the model-built data and test data sets. $50 \%$ of the total sampling points were used for model building and the other $50 \%$ of points for model testing. The sampling and modelling were carried out at 0.05 -degree resolution.

A stepwise model building approach was used. For the first step, each predictive variable was used independently and the best variable was identified on the basis of correlation coefficient and relative error. This variable was then combined with every other variable, to find the second variable that most improved the model. This procedure was repeated until all variables were included. Final selection of the model was based on the statistical diagnostics, and visual comparisons of predicted and measured maps.

The predictive variables for modelling the $C$-factor under pre-European conditions using Cubist were selected to represent the major factors presumed to determine vegetation cover and soil distribution across the continent. They can be broadly grouped into 4 categories: natural vegetation; soil parent material; climate; and geomorphology. Specifically, the following 19 predictive variables were selected: (1) Australia -Natural Vegetation (J. A. Carnahan and AUSLIG (1989) 1:5M scale); (2) aggregated geology classifications derived from the $1: 2.5 \mathrm{M}$ scale geology map of Australia; (3) the Australian Soil Classification derived from the Atlas of Australian Soils; (4) mean annual temperature, mean diurnal 


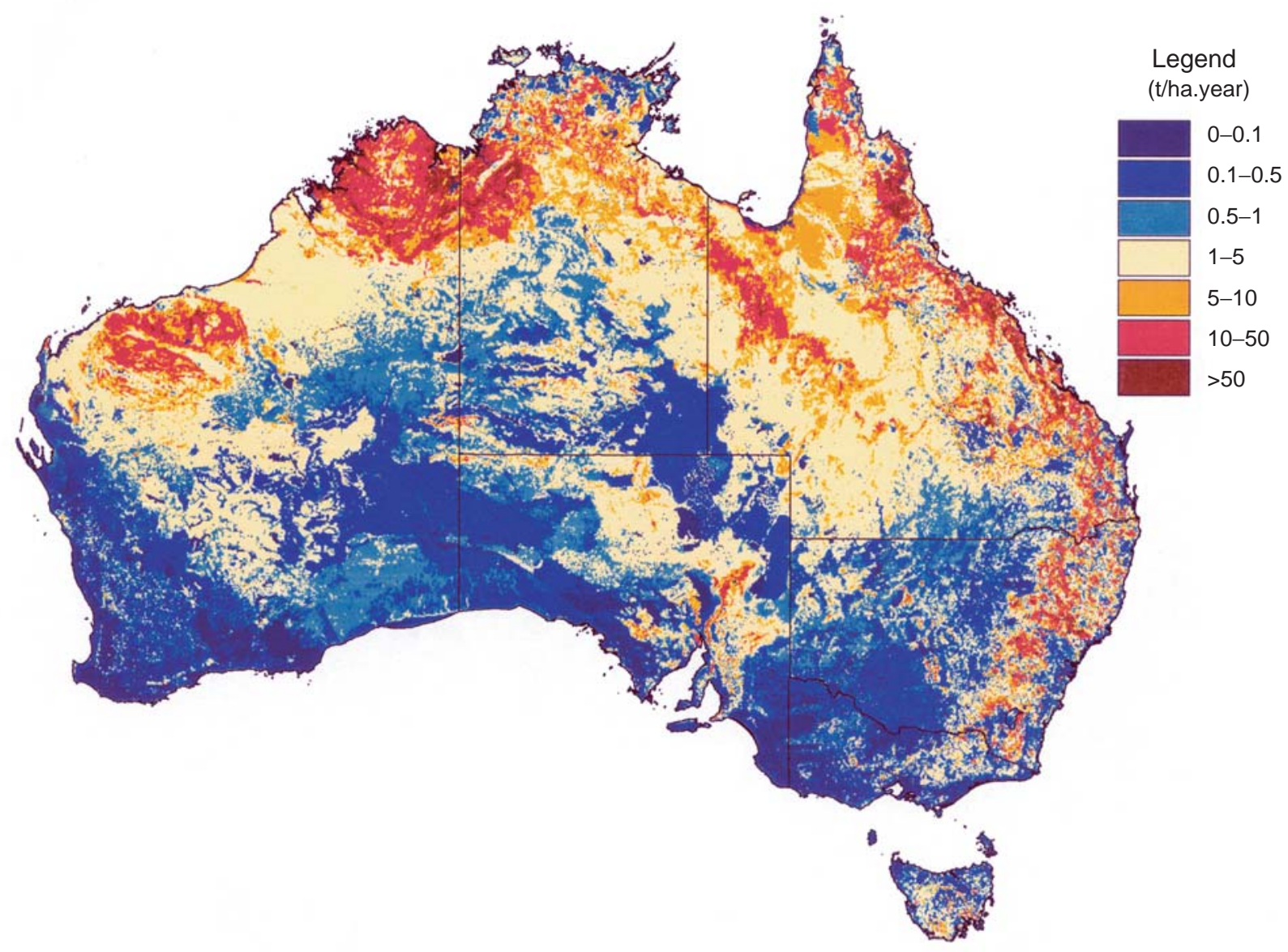

Fig. 3. Predicted rate of sheet and rill erosion under current land use for Australia. 
change, isothermality, temperature seasonality and diurnal temperature range; (5) mean annual rainfall, rainfall seasonality index, annual moisture index, and moisture index seasonality; (6) mean annual radiation and radiation seasonality; and (7) 9" DEM, averaged slope and slope length derived from 9" DEM and relief, and their scaled estimations (Gallant 2001).

\section{Results}

Figure 3 shows the predicted sheet and rill erosion and Fig. 4 shows its seasonal distribution. It was found that about $2.9 \times 10^{9}$ tonnes of soil is moved annually on hillslopes through sheetwash and rill erosion over the continent. This is 3-4 times smaller than the previous estimate (Wasson et al. 1996). Compared with a global estimate $\left(75 \times 10^{9} \mathrm{t}\right.$ /year,
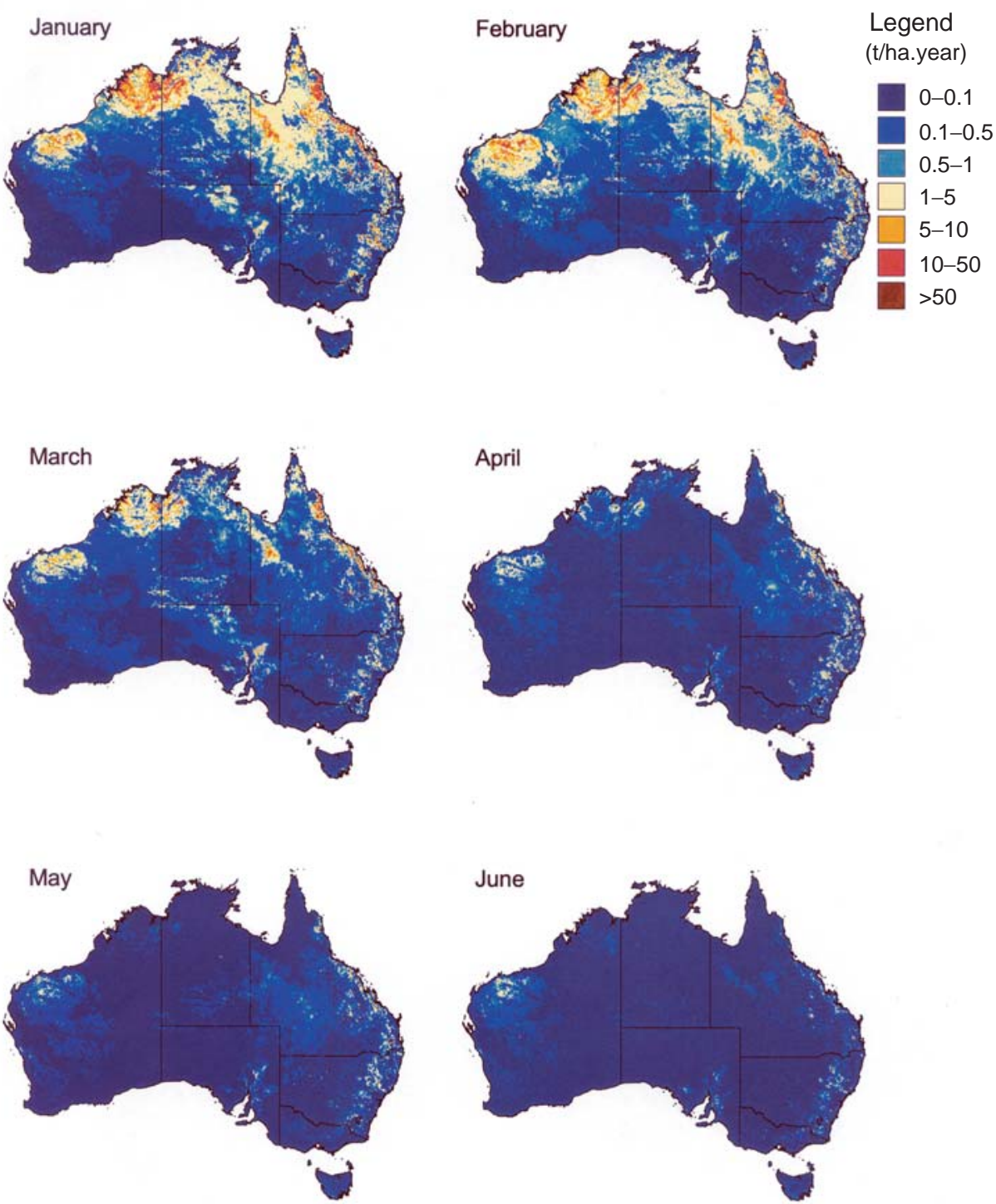

Fig. 4. Predicted monthly distribution of sheet and rill erosion under current land use for Australia. 
Pimentel et al. 1995), it is predicted that Australia contributes 3.9\% of global soil erosion from $5 \%$ of the world land area. The lower than average erosion rate in Australia is expected due to the relatively small amount of agricultural land and the flat landscape.

It is predicted that the northern part of the country has considerably more erosion potential than the southern part of the country. This agrees with general observations made from Australian erosion plot data (Freebairn 1982; Edwards 1993). This feature was not evident in the earlier continental assessment (Rosewell 1997) and is a result of the use of remote sensing time series data to represent variations in ground cover and of seasonal relationships between cover and rainfall erosivity.
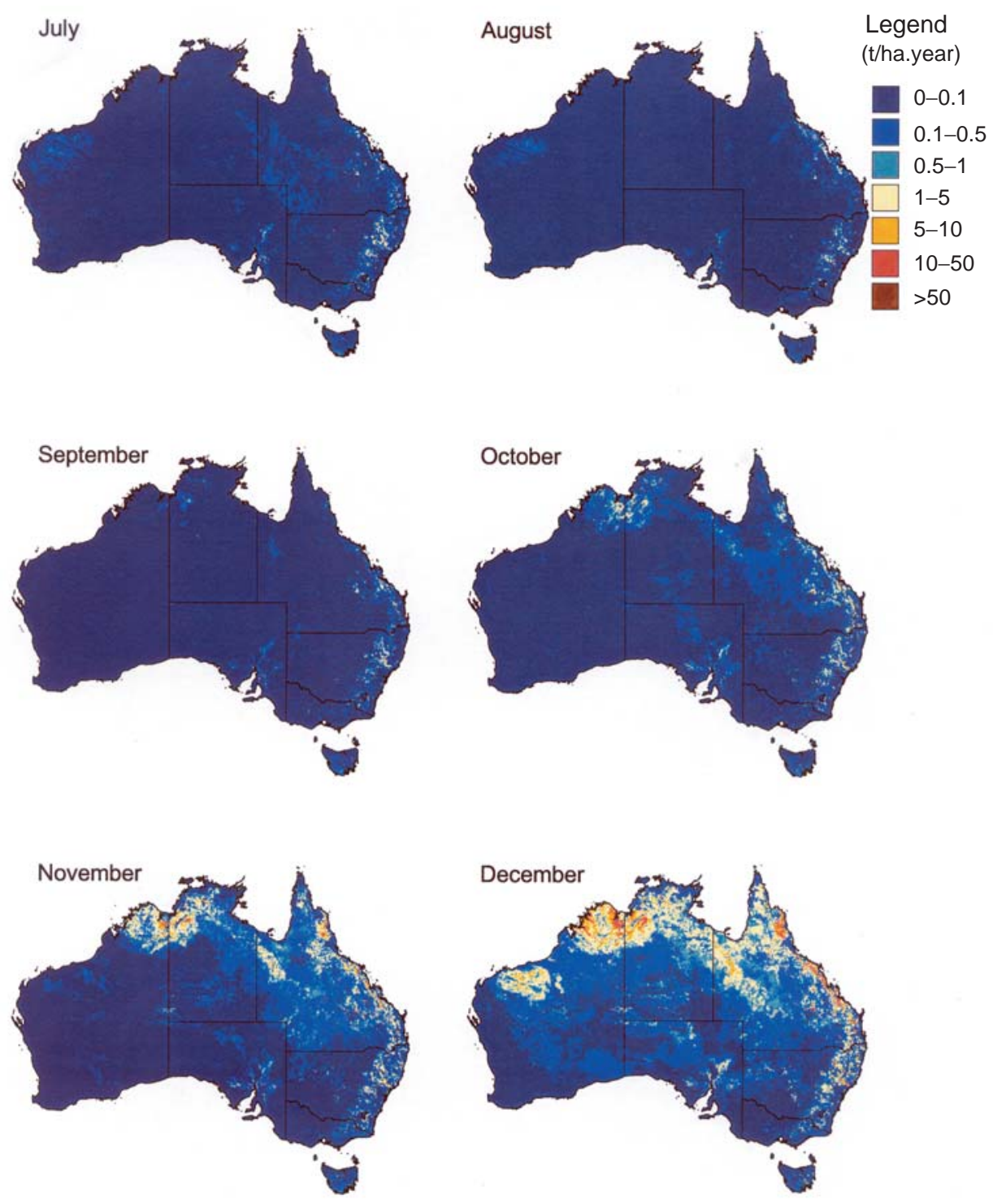

Fig. 4. (Continued). 
In addition to northern Australia, high erosion hazard is also found in the cropping belt along the eastern side of the Murray-Darling Basin, and parts of the Mount Lofty Ranges and Flinders Ranges. The erosion rate could be overestimated in some of the steeper arid and tropical mountain ranges, which are predicted to have some of the highest erosion rates in the country. The vegetation cover is sparse in those areas and the land is steep but the erosion rate is limited by shallow soils with frequent wind erosion, rock outcrops, and high gravel content. These conditions are not represented in the USLE.

The average soil erosion rate is estimated to be $4.1 \mathrm{t} / \mathrm{h}$.year and the distribution of erosion is negatively skewed toward smaller erosion rates with $28 \%$ of the continent predicted to erode at a rate $<0.5 \mathrm{t} /$ ha.year but only $8 \%$ of the continent at a rate $>10$ t/ha.year.

Much of northern Australia does not have intensive land use and the broad pattern of high soil erosion in northern Australia and lower rates in southern Australia may represent natural factors of rainfall intensity and vegetation cover. Vegetation cover in northern Australia is limited by seasonally dry conditions and very high potential evapotranspiration (Raupach et al. 2001).

To better understand the impact of land use and management practises on sheetwash and rill erosion, and to evaluate to what extent the patterns of Fig. 3 are caused by natural forces, the soil loss predictions for current land use were compared with those under natural cover. Figure 5 shows the comparison between samples of $C$-factor values extracted from the current $C$-factor map and the modelled $C$ values using $C$ ubist for those locations maintaining natural vegetation cover conditions. The same model was applied to the rest of the continent to obtain natural sheetwash and rill erosion rate. Figure 6 shows the ratio of the predictions under current cover to those for natural cover, keeping other factors constant. This reveals that erosion rates in pastoral and agricultural lands across the country are similarly accelerated above the natural rates. Rates of 5-25 times the natural rates are common in southern and northern Australia with rates in cropping lands of coastal Queensland and the northern Murray-Darling Basin predicted to be as high as 25-50 times the natural rate.

Observations show that human induced activities have increased soil erosion rates by 1-2 orders of magnitude over natural rates (Neil and Fogarty 1991; Prove et al. 1995; Edwards and Zierholz 2001). Neil and Galloway (1989) concluded that erosion rates in the southern Tablelands of New South Wales from cropped areas were about 2.8 times greater than those from native forests. Similar rates were found by recent studies of sediment yield from farm dams in west of Sydney region (Erskine et al. 2002, 2003; Mahmoudzadeh et al. 2002). Accelerated erosion rates were estimated at 10-50 times natural rates in NSW (Edwards and Zierholz 2001), and up to 100 times near Canberra (Neil and Fogarty 1991). Our predicted accelerated rates of erosion are in agreement with those observations. It was also shown that, although erosion rates in agricultural lands of southern Australia are generally lower than those in northern Australia, they are still many times greater than their natural rates.

A review of published measurements of sheetwash and rill erosion across Australia was conducted to evaluate the overall accuracy of the USLE predictions. The data are presented in Table 1. They are composed of 3 types of data: measurements of sediment loss from erosion plots (e.g. Freebairn and Wockner 1986; Edwards 1987); sediment yields to farm dams with small ungullied catchments (Erskine et al. 2002, 2003); and measurements of Caesium-137 inventories in soil correlated with erosion plot data (e.g. Loughran and Elliot 1996; McFarlane et al. 2000). 


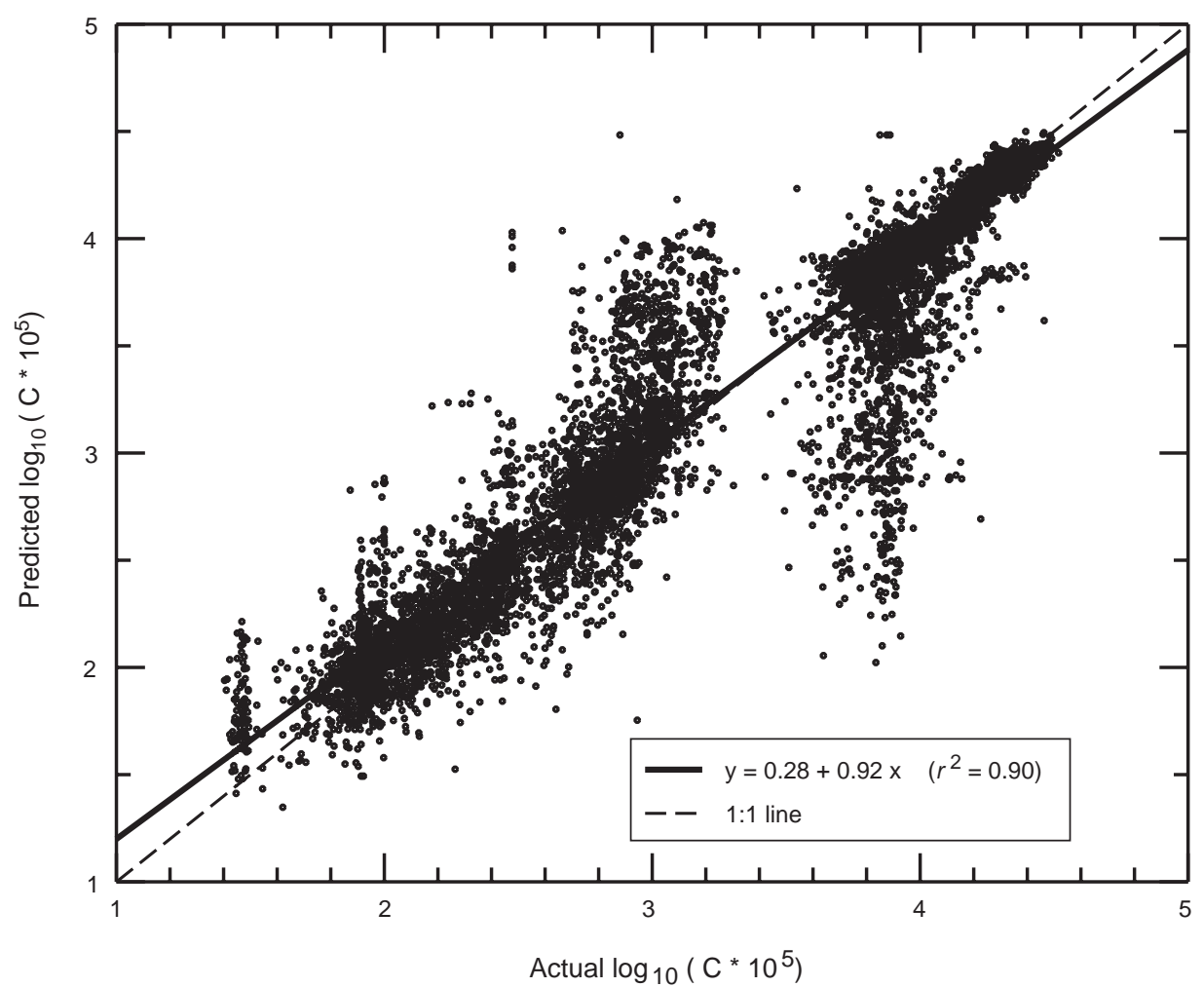

Fig. 5. Comparison between natural $C$-factor values modeled using Cubist and those extracted from $C$-factor map at the locations of minimum cover disturbance. There are 9916 points in total. The line of best fit and 1:1 line are shown.

The comparison with predictions was made between the averaged values for measurements and average predicted values for the given land use and locations. The radius used for calculating the average prediction was $0.05^{\circ}$ where exact site locations were available to $0.5^{\circ}$ where only the locations of the nearest town or other geographic features were available. In some cases, additional information, such as slope percentage, is used for better locating the measurement locations and land use groups. We used the averaged values of predicted annual erosion rate from those windows because, in many cases the land uses, localised topographic and soil conditions described by the experiments do not represent the dominant land use in the $0.01^{\circ}$ grid cell used in this study. Furthermore, the vegetation cover was derived from $0.08^{\circ}$ resolution NDVI time series. Only 3 broad categorised land use groups (cropping, grazing/pasture, and woodland) were used. Together with these averaging windows, the total number of effective measurements for comparison was reduced to 83 sites.

Figure 7 shows the comparison between the averaged annual erosion rate from our predictions and the mean values of measurements for those 83 sites. Both observations and predictions varied over 3 orders of magnitude across the continent. For consistency, we converted the measurements with multiple values listed in Table 1 to their annual averages with the consideration of the cultivation and harvest cycle as we did in the $C$-factor modelling. For instance, for canelands where 4 years cultivation cycle was assumed in our 


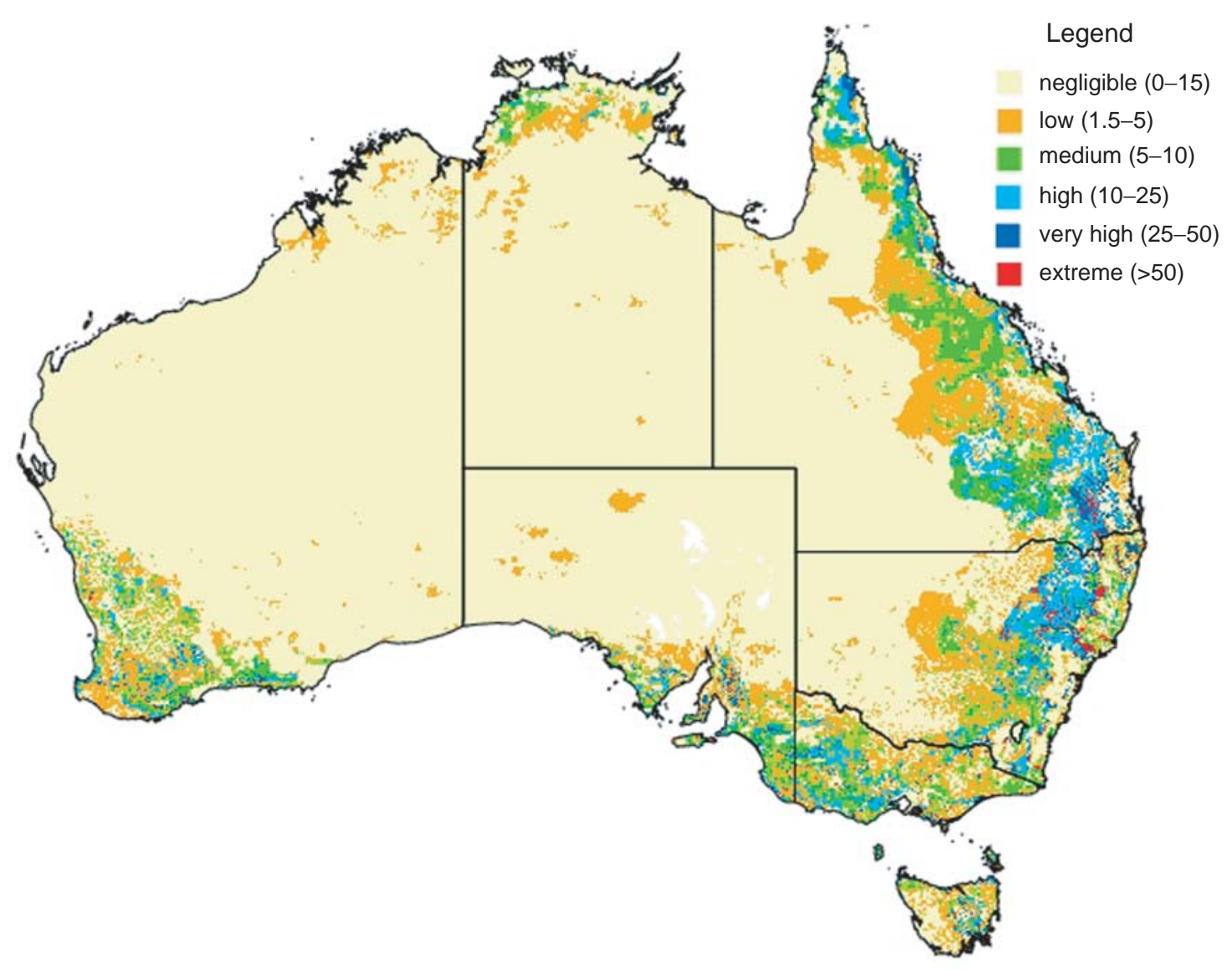

Fig. 6. Estimated soil loss ratio between current and pre-European settlement. Map shows the acceleration of sheetwash and rill erosion since European settlement. It is modelled by the ratio between current and pre-European settlement sheetwash and rill erosion rate. The ratio values are shown in the brackets. 
study, the mean values of measurements were estimated by 1 year of maximum measured erosion rate (bare soil), 1 year of medium rate (plant establishing period), and 2 years of minimum measured rate (plant well established period). If only 2 measurement values exist, the medium rate is assumed to be equal to minimum measured. Similar rules were applied for plantations. The differences between mean values of prediction and measurements are generally within a factor of 10 . We have also calculated the standard deviation of measurements and predictions. For measurements, these can be inter-annual variations, or variations between plots at a site. For the predictions, they are the variations we found within the window analysed. To maintain clarity, these standard deviations have not been shown but both measurements and predictions at a location vary by 5-10 times, illustrating the extreme variability of soil erosion. Some of the measurements themselves have error associated with them or depend upon assumptions. The Caesium-137 data, for example, is reliant on empirical correlations with erosion plot data for different land use groups in NSW that was then applied across the continent. Given these constraints, there is good agreement between the predicted and the measured rates. The $R^{2}$ was estimated linearly to be 0.64 with root mean squared error of $3.84 \mathrm{t} / \mathrm{ha}$.year. There are no systematic variations in the residuals.

The predictions match USLE plot measurements in cropping land (Edwards 1987) best, because the model was initially built from that type of data. Nevertheless, the predicted long-term averaged erosion rates for cropping land can differ from the field measurements, due to our assumption that the cropping lands were under conventional cultivation with stubble retained cover management. It is expected that reduced-tillage or no-tillage would produce lower erosion rates under the same cover management practices. Similarly, in the short-term, logging and bushfires in forest lands can alter erosion rates significantly. Measurements show that erosion rates reach $62 \mathrm{t} /$ ha.year after bushfire (Atkinson 1984) and $101 \mathrm{t} /$ ha.year (Wallbrink et al. 2002) after forest harvesting. Those effects were not considered in our estimations. The overestimations of some measurements of low soil erosion shown in Fig. 7 are for forest lands in SE Australia, conditions for which there are little data on which to calibrate the USLE.

Table 2 divides the predictions into land use classes. These can be compared with an aggregation of the measurements of Table 1 into major land use classes (Fig. 8). There is up to 2-3 orders of magnitude variation of soil loss rate within each land use group, showing the importance of environmental factors in determining local erosion rate. Similarly, within a local environment both the predicted and observed erosion rates can vary by as much as 2 orders of magnitude between land uses.

In general, total soil loss is dominated by the pastoral industries, including grazed woodlands, because of the vast area that these land uses occupy. The average predicted rate is higher than that shown for permanent pasture in Fig. 8 because the measurements are biased towards southern Australia, whereas the bulk of the land use occurs in northern Australia. No systematic overestimate is found when comparing on a site basis. This illustrates the value of a model for making assessments across a vast area of varying conditions. Comparisons with the predicted rates under natural cover suggest that native pastures are eroding at 2-3 times the natural rates. The woodlands are predicted to be eroding at about the same rate as under natural conditions, but the more heavily grazed savannah woodlands of Queensland are predicted to be eroding at 2-10 times the rate expected with undisturbed cover (see Fig. 5).

Agricultural lands are both predicted and observed to have the highest erosion rates, although cereal cropping and improved pastures can have similar erosion rates to 
Table 1. Soil loss data from plot and Caesium-137 based measurements sorted by ascending rainfall erosivity

Values of rainfall erosivity are extracted from the national $R$-factor map ( $\mathrm{Lu}$ and $\mathrm{Yu}$ 2002). The longitude and latitude given in the table vary in accuracy.

Some were supplied by the original authors to pinpoint the actual experimental site. Others apply only to the region from where the data was collected

\begin{tabular}{|c|c|c|c|c|c|}
\hline Location & $\begin{array}{l}\text { Long. } \\
\text { (E) }\end{array}$ & $\begin{array}{l}\text { Lat. } \\
(\mathrm{S})\end{array}$ & $\begin{array}{l}\text { Rainfall erosivity } \\
\text { (MJ.mm/ha.h.year) }\end{array}$ & $\begin{array}{c}\text { Soil loss rate } \\
\text { (t/ha.year) }\end{array}$ & Source \\
\hline \multicolumn{6}{|c|}{ Cultivated bare soil (including mining) } \\
\hline Wagga Wagga, NSW & $147^{\circ} 21^{\prime} 6^{\prime \prime}$ & $35^{\circ} 7^{\prime} 24^{\prime \prime}$ & 822.5 & $2.0-59.4$ & Freebairn (1982); Rosewell (1986) \\
\hline Cowra, NSW & $148^{\circ} 41^{\prime} 24^{\prime \prime}$ & $33^{\circ} 49^{\prime} 52^{\prime \prime}$ & 921.8 & 31.3 & Rosewell (1986) \\
\hline Hunter Valley & $150^{\circ} 59^{\prime}$ & $32^{\circ} 5^{\prime}$ & 1227.1 & $0.4-11.8$ & Elliott and Dight (1986) \\
\hline Ginninderra, ACT & $149^{\circ} 7^{\prime}$ & $35^{\circ} 11^{\prime}$ & 1461.1 & 44.0 & Kinnell (1983) \\
\hline Gunnedah, NSW & $150^{\circ} 15^{\prime} 41^{\prime \prime}$ & $30^{\circ} 59^{\prime} 11^{\prime \prime}$ & 1489.4 & $7.0-87.0$ & Freebairn (1982); Rosewell (1986) \\
\hline Greenwood, Qld & $151^{\circ} 44^{\prime}$ & $27^{\circ} 20^{\prime}$ & 1807.5 & 36.0 & Freebairn (1982) \\
\hline Inverell, NSW & $151^{\circ} 7^{\prime} 0^{\prime \prime}$ & $29^{\circ} 46^{\prime} 35^{\prime \prime}$ & 1949.1 & 51.4 & Rosewell (1986) \\
\hline Greenmount, Qld & $151^{\circ} 57^{\prime}$ & $27^{\circ} 45^{\prime}$ & 2273.2 & 53.0 & Freebairn (1982) \\
\hline Nambour, Qld & $152^{\circ} 57^{\prime}$ & $26^{\circ} 37^{\prime}$ & 9043.5 & 148.0 & Freebairn (1982) \\
\hline Mackay, Qld & $149^{\circ} 11^{\prime}$ & $21^{\circ} 8^{\prime}$ & 10356.1 & 227.0 & Sallaway (1979) \\
\hline Jabiru, NT & $132^{\circ} 50^{\prime}$ & $12^{\circ} 40^{\prime}$ & 12569.9 & $20-102$ & Edwards (1993) \\
\hline Innisfail, Qld & $146^{\circ} 1^{\prime}$ & $17^{\circ} 31^{\prime}$ & 21891.3 & $47-505$ & Freebairn (1982); Prove et al. (1995) \\
\hline \multicolumn{6}{|c|}{ Cropped (including horticulture, canelands, crop/pasture rotation) } \\
\hline Murrayville, Vic. & $141^{\circ} 11^{\prime} 2^{\prime \prime}$ & $35^{\circ} 16^{\prime} 16^{\prime \prime}$ & 247.7 & 4.17 & Loughran and Elliot (1996) \\
\hline Cleve, SA & $136^{\circ} 29^{\prime} 29^{\prime \prime}$ & $33^{\circ} 42^{\prime} 34^{\prime \prime}$ & 257.8 & $0.4-8.16$ & Loughran and Elliot (1996) \\
\hline Ouyen, Vic. & $142^{\circ} 19^{\prime} 1^{\prime \prime}$ & $35^{\circ} 4^{\prime} 4^{\prime \prime}$ & 268.2 & 7.7 & Loughran and Elliot (1996) \\
\hline Kaniva, Vic. & $141^{\circ} 14^{\prime} 20^{\prime \prime}$ & $36^{\circ} 22^{\prime} 37^{\prime \prime}$ & 288.4 & 4.01 & Loughran and Elliot (1996) \\
\hline Kellerberrin, WA & $117^{\circ} 42^{\prime} 30^{\prime \prime}$ & $31^{\circ} 38^{\prime} 10^{\prime \prime}$ & 296.0 & $3.5-26.7$ & McFarlane et al. (2000) \\
\hline Whyte Yarcowie, SA & $138^{\circ} 53^{\prime} 5^{\prime \prime}$ & $33^{\circ} 14^{\prime} 17^{\prime \prime}$ & 313.2 & 0.64 & Loughran and Elliot (1996) \\
\hline Horsham, Vic. & $142^{\circ} 11^{\prime} 36^{\prime \prime}$ & $36^{\circ} 42^{\prime} 54^{\prime \prime}$ & 337.0 & 0.52 & Loughran and Elliot (1996) \\
\hline Swan Hill, Vic. & $143^{\circ} 32^{\prime} 50^{\prime \prime}$ & $35^{\circ} 20^{\prime} 36^{\prime \prime}$ & 338.7 & 4.3 & Loughran and Elliot (1996) \\
\hline Gabalong, WA & $116^{\circ} 23^{\prime}$ & $30^{\circ} 43^{\prime}$ & 342.0 & $6.8-13.1$ & McFarlane et al. (2000) \\
\hline Kapunda, SA & $138^{\circ} 54^{\prime} 44^{\prime \prime}$ & $34^{\circ} 20^{\prime} 47^{\prime \prime}$ & 348.8 & 1.98 & Loughran and Elliot (1996) \\
\hline North Bodallin, WA & $118^{\circ} 56^{\prime}$ & $31^{\circ} 7^{\prime}$ & 371.0 & 6.4 & McFarlane et al. (2000) \\
\hline Saddleworth, SA & $138^{\circ} 46^{\prime} 28^{\prime \prime}$ & $34^{\circ} 5^{\prime} 15^{\prime \prime}$ & 388.4 & 1.25 & Loughran and Elliot (1996) \\
\hline Spalding, SA & $138^{\circ} 36^{\prime} 24^{\prime \prime}$ & $33^{\circ} 30^{\prime} 24^{\prime \prime}$ & 409.8 & 0.57 & Loughran and Elliot (1996) \\
\hline
\end{tabular}


Table 1. (Continued)

\begin{tabular}{|c|c|c|c|c|c|}
\hline Location & $\begin{array}{l}\text { Long. } \\
\text { (E) }\end{array}$ & $\begin{array}{l}\text { Lat. } \\
(\mathrm{S})\end{array}$ & $\begin{array}{l}\text { Rainfall erosivity } \\
\text { (MJ.mm/ha.h.year) }\end{array}$ & $\begin{array}{l}\text { Soil loss rate } \\
\text { (t/ha.year) }\end{array}$ & Source \\
\hline Bundaleer, SA & $138^{\circ} 29^{\prime}$ & $33^{\circ} 18^{\prime}$ & 442.5 & 0.26 & Loughran and Elliot (1996) \\
\hline Northam, WA & $116^{\circ} 40^{\prime} 0^{\prime \prime}$ & $31^{\circ} 39^{\prime} 27^{\prime \prime}$ & 450.0 & $2.5-20.7$ & McFarlane et al. (2000) \\
\hline Strathalbyn, SA & $138^{\circ} 53^{\prime} 22^{\prime \prime}$ & $35^{\circ} 15^{\prime} 51^{\prime \prime}$ & 472.3 & 3.0 & Loughran and Elliot (1996) \\
\hline Jamestown, SA & $138^{\circ} 36^{\prime} 29^{\prime \prime}$ & $33^{\circ} 12^{\prime} 34^{\prime \prime}$ & 494.2 & $0.01-0.72$ & Loughran and Elliot (1996) \\
\hline Charlton, Vic. & $143^{\circ} 12^{\prime} 58^{\prime \prime}$ & $36^{\circ} 15^{\prime} 43^{\prime \prime}$ & 541.6 & 0.89 & Loughran and Elliot (1996) \\
\hline St Arnaud, Vic. & $143^{\circ} 18^{\prime} 58^{\prime \prime}$ & $36^{\circ} 36^{\prime} 43^{\prime \prime}$ & 595.8 & 1.41 & Loughran and Elliot (1996) \\
\hline Colbinabbin, Vic. & $144^{\circ} 19^{\prime} 2^{\prime \prime}$ & $36^{\circ} 35^{\prime} 52^{\prime \prime}$ & 643.7 & 3.06 & Loughran and Elliot (1996) \\
\hline Ballarat, Vic. & $143^{\circ} 50^{\prime} 39^{\prime \prime}$ & $37^{\circ} 33^{\prime} 40^{\prime \prime}$ & 647.4 & 4.89 & Loughran and Elliot (1996) \\
\hline Werribee, Vic. & $144^{\circ} 39^{\prime} 23^{\prime \prime}$ & $37^{\circ} 53^{\prime} 56^{\prime \prime}$ & 655.4 & 0.02 & Loughran and Elliot (1996) \\
\hline Woodside, SA & $138^{\circ} 52^{\prime}$ & $34^{\circ} 57^{\prime}$ & 694.0 & $2.56-12.8$ & Loughran and Elliot (1996) \\
\hline Mintaro, SA & $138^{\circ} 43^{\prime} 1^{\prime \prime}$ & $33^{\circ} 55^{\prime} 31^{\prime \prime}$ & 705.1 & 1.34 & Loughran and Elliot (1996) \\
\hline Tas. & - & - & $350.0-750.0$ & $0.3-5.3$ & Cullen (1995) \\
\hline Wagga Wagga, NSW & $147^{\circ} 21^{\prime} 6^{\prime \prime}$ & $35^{\circ} 7^{\prime} 24^{\prime \prime}$ & 822.5 & $0.2-2.9$ & Edwards (1987) \\
\hline Cowra, NSW & $148^{\circ} 41^{\prime} 24^{\prime \prime}$ & $33^{\circ} 49^{\prime} 52^{\prime \prime}$ & 921.8 & $0.1-11.9$ & Edwards (1987) \\
\hline Donnybrook, WA & $115^{\circ} 49^{\prime} 27^{\prime \prime}$ & $33^{\circ} 34^{\prime} 37^{\prime \prime}$ & 1088.6 & $1.4-18.9$ & McFarlane et al. (2000) \\
\hline Wellington, NSW & $148^{\circ} 57^{\prime} 2^{\prime \prime}$ & $32^{\circ} 33^{\prime} 36^{\prime \prime}$ & 1239.3 & $0.0-1.7$ & Edwards (1987) \\
\hline Gunnedah, NSW & $150^{\circ} 15^{\prime} 41^{\prime \prime}$ & $30^{\circ} 59^{\prime} 11^{\prime \prime}$ & 1489.4 & $0.6-9.6$ & Edwards (1987) \\
\hline Trentham, Vic. & $144^{\circ} 19^{\prime} 2^{\prime \prime}$ & $37^{\circ} 23^{\prime} 40^{\prime \prime}$ & 1639.7 & 1.92 & Loughran and Elliot (1996) \\
\hline Silvan, Vic. & $145^{\circ} 25^{\prime}$ & $37^{\circ} 49^{\prime}$ & 1677.5 & 3.35 & Loughran and Elliot (1996) \\
\hline Greenwood, Qld & $151^{\circ} 44^{\prime}$ & $27^{\circ} 20^{\prime}$ & 1807.5 & $1.8-19.8$ & Freebairn and Wockner (1986) \\
\hline Inverell, NSW & $151^{\circ} 7^{\prime} 0^{\prime \prime}$ & $29^{\circ} 46^{\prime} 35^{\prime \prime}$ & 1949.1 & $0.0-14.6$ & Edwards (1987) \\
\hline Brigalow, Qld & $150^{\circ} 47^{\prime} 44^{\prime \prime}$ & $26^{\circ} 50^{\prime} 48^{\prime \prime}$ & 1985.3 & 14.7 & Loughran and Elliot (1996) \\
\hline Greenmount, Qld & $151^{\circ} 57^{\prime}$ & $27^{\circ} 45^{\prime}$ & 2273.2 & $2.1-22.3$ & Freebairn and Wockner (1986) \\
\hline Earlsfield, Qld & $150^{\circ} 23^{\prime}$ & $24^{\circ} 11^{\prime}$ & 2410.1 & 5.5 & Loughran and Elliot (1996) \\
\hline Faulconbridge, NSW & $150^{\circ} 32^{\prime}$ & $33^{\circ} 41^{\prime}$ & 2834.0 & $6.1-7.2$ & Erskine et al. (2002) \\
\hline Somersby, NSW & $151^{\circ} 25^{\prime}$ & $33^{\circ} 16^{\prime}$ & 3981.5 & $4.7-10.2$ & Erskine et al. (2002) \\
\hline SE, Qld & $152^{\circ} 48^{\prime}$ & $26^{\circ} 4^{\prime}$ & 4234.1 & $1.9-199.0$ & Yu et al. (2000) \\
\hline Imbil, Qld & $152^{\circ} 40^{\prime} 55^{\prime \prime}$ & $26^{\circ} 27^{\prime} 39^{\prime \prime}$ & 5327.6 & $5.0-178.0$ & $\begin{array}{l}\text { Ciesiolka et al (1995); Palis et al. } \\
\text { (1997) }\end{array}$ \\
\hline
\end{tabular}


Table 1. (Continued)

\begin{tabular}{|c|c|c|c|c|c|}
\hline Location & $\begin{array}{l}\text { Long. } \\
(\mathrm{E})\end{array}$ & $\begin{array}{l}\text { Lat. } \\
(\mathrm{S})\end{array}$ & $\begin{array}{l}\text { Rainfall erosivity } \\
\text { (MJ.mm/ha.h.year) }\end{array}$ & $\begin{array}{l}\text { Soil loss rate } \\
\text { (t/ha.year) }\end{array}$ & Source \\
\hline Comboyne, NSW & $152^{\circ} 28^{\prime} 23^{\prime \prime}$ & $31^{\circ} 36^{\prime} 38^{\prime \prime}$ & 7543.9 & $1.0-44.8$ & Loughran and Elliot (1996) \\
\hline Nambour, Qld & $152^{\circ} 57^{\prime}$ & $26^{\circ} 37^{\prime}$ & 9043.5 & $7.0-36.4$ & Capelin and Truong (1985) \\
\hline Innisfail, Qld & $144^{\circ} 55^{\prime}-146^{\circ} 03^{\prime}$ & $17^{\circ} 18^{\prime}-17^{\circ} 40^{\prime}$ & $9109.5-40631.7$ & $5-148$ & Prove et al. (1995) \\
\hline \multicolumn{6}{|c|}{ Grazing lands } \\
\hline Southern WA & - & - & $250.0-400.0$ & 1.0 & McFarlane et al. (2000) \\
\hline Benalla, Vic. & $145^{\circ} 58^{\prime} 32^{\prime \prime}$ & $36^{\circ} 13^{\prime} 19^{\prime \prime}$ & 634.9 & 0.89 & Loughran and Elliot (1996) \\
\hline Stawell, Vic. & $142^{\circ} 46^{\prime} 18^{\prime \prime}$ & $37^{\circ} 3^{\prime} 51^{\prime \prime}$ & 646.7 & 0.0 & Loughran and Elliot (1996) \\
\hline Wagga Wagga, NSW & $147^{\circ} 21^{\prime} 6^{\prime \prime}$ & $35^{\circ} 7^{\prime} 24^{\prime \prime}$ & 822.5 & $0.1-0.3$ & Edwards (1987) \\
\hline Yea, Vic. & $145^{\circ} 25^{\prime} 36^{\prime \prime}$ & $37^{\circ} 13^{\prime} 13^{\prime \prime}$ & 884.0 & $0.0-0.9$ & Loughran and Elliot (1996) \\
\hline Cowra, NSW & $148^{\circ} 41^{\prime} 24^{\prime \prime}$ & $33^{\circ} 49^{\prime} 52^{\prime \prime}$ & 921.8 & $0.03-1.3$ & Edwards (1987) \\
\hline Leongatha, Vic. & $145^{\circ} 56^{\prime} 30^{\prime \prime}$ & $38^{\circ} 28^{\prime} 59^{\prime \prime}$ & 990.4 & 0.6 & Loughran and Elliot (1996) \\
\hline Scone, NSW & $150^{\circ} 52^{\prime} 21^{\prime \prime}$ & $32^{\circ} 3^{\prime} 24^{\prime \prime}$ & 1224.1 & $0.0-0.1$ & Edwards (1987) \\
\hline Tallangatta,Vic. & $147^{\circ} 11^{\prime} 12^{\prime \prime}$ & $36^{\circ} 13^{\prime} 2^{\prime \prime}$ & 1236.6 & 0.0 & Loughran and Elliot (1996) \\
\hline Wellington, NSW & $148^{\circ} 57^{\prime} 2^{\prime \prime}$ & $32^{\circ} 33^{\prime} 36^{\prime \prime}$ & 1239.3 & 0.84 & Edwards (1987) \\
\hline Gunnedah, NSW & $150^{\circ} 15^{\prime} 41^{\prime \prime}$ & $30^{\circ} 59^{\prime} 11^{\prime \prime}$ & 1489.4 & $1.1-4.0$ & $\begin{array}{l}\text { Edwards (1987); Lang and McCaffery } \\
\text { (1984) }\end{array}$ \\
\hline Beaconsfield, Qld & $144^{\circ} 35^{\prime} 30^{\prime \prime}$ & $23^{\circ} 19^{\prime} 44^{\prime \prime}$ & 1516.5 & $2.0-4.1$ & Loughran and Elliot (1996) \\
\hline Silvan, Vic. & $145^{\circ} 25^{\prime}$ & $37^{\circ} 49^{\prime}$ & 1677.5 & 0.68 & Loughran and Elliot (1996) \\
\hline Coolah, NSW & $149^{\circ} 43^{\prime} 18^{\prime \prime}$ & $31^{\circ} 50^{\prime} 7^{\prime \prime}$ & 1724.2 & $0.5-1.2$ & Loughran and Elliot (1996) \\
\hline Pokolbin, NSW & $151^{\circ} 17^{\prime}$ & $32^{\circ} 47^{\prime}$ & 1869.8 & $0.2-1.5$ & Loughran and Elliot (1996) \\
\hline Inverell, NSW & $151^{\circ} 7^{\prime} 0^{\prime \prime}$ & $29^{\circ} 46^{\prime} 35^{\prime \prime}$ & 1949.1 & $0.51-0.86$ & Edwards (1987) \\
\hline Oombabeer, Qld & $149^{\circ} 31^{\prime}$ & $24^{\circ} 30^{\prime}$ & 2244.5 & 2.5 & Loughran and Elliot (1996) \\
\hline Springvale, Qld & $147^{\circ} 30^{\prime}$ & $23^{\circ} 40^{\prime}$ & 2318.8 & $0.014-21.1$ & Ciesiolka (1987) \\
\hline Faulconbridge, NSW & $150^{\circ} 32^{\prime}$ & $33^{\circ} 41^{\prime}$ & 2834.0 & $2.7-4.6$ & Erskine et al. (2002) \\
\hline Hawkesbury, NSW & $151^{\circ} 02^{\prime}$ & $33^{\circ} 43^{\prime}$ & 3212.6 & $1.4-5.1$ & Erskine et al. (2002) \\
\hline Kangaroo Hills, Qld & $145^{\circ} 40^{\prime} 39^{\prime \prime}$ & $18^{\circ} 55^{\prime} 37^{\prime \prime}$ & 3299.8 & 1.9 & Loughran and Elliot (1996) \\
\hline Monkerai, NSW & $151^{\circ} 52^{\prime}$ & $32^{\circ} 14^{\prime}$ & 3587.7 & 0.1 & Loughran and Elliot (1996) \\
\hline Comboyne, NSW & $152^{\circ} 28^{\prime} 23^{\prime \prime}$ & $31^{\circ} 36^{\prime} 38^{\prime \prime}$ & 7543.9 & 0.07 & Loughran and Elliot (1996) \\
\hline
\end{tabular}


Table 1. (Continued)

\begin{tabular}{|c|c|c|c|c|c|}
\hline Location & $\begin{array}{l}\text { Long. } \\
\text { (E) }\end{array}$ & $\begin{array}{l}\text { Lat. } \\
\text { (S) }\end{array}$ & $\begin{array}{l}\text { Rainfall erosivity } \\
\text { (MJ.mm/ha.h.year) }\end{array}$ & $\begin{array}{l}\text { Soil loss rate } \\
\text { (t/ha.year) }\end{array}$ & Source \\
\hline Pilbara-Gascoyne, WA & $114^{\circ} 25^{\prime}-119^{\circ} 43^{\prime}$ & $24^{\circ} 49^{\prime}-23^{\circ} 21^{\prime}$ & $400.0-5000.0$ & 14.5 & McFarlane et al. (2000) \\
\hline Kiimberley, WA & - & - & $4000.0-9000.0$ & 13.5 & McFarlane et al. (2000) \\
\hline \multicolumn{6}{|c|}{ Pasture (light or no grazing) } \\
\hline Wagga Wagg, NSW & $147^{\circ} 21^{\prime} 6^{\prime \prime}$ & $35^{\circ} 7^{\prime} 24^{\prime \prime}$ & 822.5 & $0.01-0.02$ & Edwards (1987) \\
\hline Cowra, NSW & $148^{\circ} 41^{\prime} 24^{\prime \prime}$ & $33^{\circ} 49^{\prime} 52^{\prime \prime}$ & 921.8 & $0.0-0.1$ & Edwards (1987) \\
\hline Scone, NSW & $150^{\circ} 52^{\prime} 21^{\prime \prime}$ & $32^{\circ} 3^{\prime} 24^{\prime \prime}$ & 1224.1 & $0.0-0.01$ & Edwards (1987) \\
\hline Hunter Valley, NSW & $150^{\circ} 59^{\prime}$ & $32^{\circ} 5^{\prime}$ & 1227.1 & $0.9-1.0$ & Elliott and Dight (1986) \\
\hline Wellington, NSW & $148^{\circ} 57^{\prime} 2^{\prime \prime}$ & $32^{\circ} 33^{\prime} 36^{\prime \prime}$ & 1239.3 & $0.0-0.1$ & Edwards (1987) \\
\hline Gunnedah, NSW & $150^{\circ} 15^{\prime} 41^{\prime \prime}$ & $30^{\circ} 59^{\prime} 11^{\prime \prime}$ & 1489.4 & $0.0-1.1$ & Edwards (1987) \\
\hline Inverell, NSW & $151^{\circ} 7^{\prime} 0^{\prime \prime}$ & $29^{\circ} 46^{\prime} 35^{\prime \prime}$ & 1949.1 & $0.07-0.19$ & Edwards (1987) \\
\hline Banana, Qld & $150^{\circ} 8^{\prime} 1^{\prime \prime}$ & $24^{\circ} 28^{\prime} 29^{\prime \prime}$ & 2227.3 & 0.1 & Loughran and Elliot (1996) \\
\hline Medway, Qld & $147^{\circ} 20^{\prime}$ & $23^{\circ} 48^{\prime}$ & 2297.0 & $0.1-1.5$ & Ciesiolka (1987) \\
\hline Burdekin, Qld & $146^{\circ} 22^{\prime}$ & $19^{\circ} 51^{\prime}$ & 2570.7 & $0.0-0.01$ & Loughran and Elliot (1996) \\
\hline \multicolumn{6}{|c|}{ Woodlands (including forest and scrub) } \\
\hline Lidsdale, NSW & $150^{\circ} 5^{\prime}$ & $33^{\circ} 23^{\prime}$ & 1613.2 & $0.1-7.0$ & Humphreys and Mitchell (1983) \\
\hline Tanjil Bren, Vic. & $146^{\circ} 10^{\prime}$ & $37^{\circ} 49^{\prime}$ & 1614.8 & 1.90 & Loughran and Elliot (1996) \\
\hline Pokolbin, NSW & $151^{\circ} 17^{\prime}$ & $32^{\circ} 47^{\prime}$ & 1869.8 & 0.5 & Loughran and Elliot (1996) \\
\hline Brigalow, Qld & $150^{\circ} 47^{\prime} 44^{\prime \prime}$ & $26^{\circ} 50^{\prime} 48^{\prime \prime}$ & 1985.3 & 0.0 & Loughran and Elliot (1996) \\
\hline Shoalhaven, NSW & $150^{\circ} 15^{\prime}$ & $34^{\circ} 47^{\prime}$ & 1990.4 & $0.0-4.3$ & Williams (1973) \\
\hline Jambin, Qld & $150^{\circ} 22^{\prime} 19^{\prime \prime}$ & $24^{\circ} 11^{\prime} 55^{\prime \prime}$ & 2305.9 & 0.36 & Loughran and Elliot (1996) \\
\hline Cattai, NSW & $150^{\circ} 55^{\prime}$ & $33^{\circ} 33^{\prime}$ & 2353.8 & $0.0-0.3$ & Humphreys and Mitchell (1983) \\
\hline Faulconbridge, NSW & $150^{\circ} 32^{\prime}$ & $33^{\circ} 41^{\prime}$ & 2834.0 & $2.0-3.1$ & Erskine et al. (2002) \\
\hline Hawkesbury, NSW & $151^{\circ} 02^{\prime}$ & $33^{\circ} 43^{\prime}$ & 3212.6 & 4.2 & Erskine et al. (2002) \\
\hline Narrabeen, NSW & $151^{\circ} 17^{\prime}$ & $33^{\circ} 41^{\prime}$ & 5275.5 & $2.4-8.0$ & Blong et al. (1982) \\
\hline Cordeaux, NSW & $150^{\circ} 45^{\prime}$ & $34^{\circ} 24^{\prime}$ & 5308.0 & $0.0-0.7$ & Humphreys and Mitchell (1983) \\
\hline NT & - & - & - & $0.2-2.4$ & Williams (1973) \\
\hline
\end{tabular}




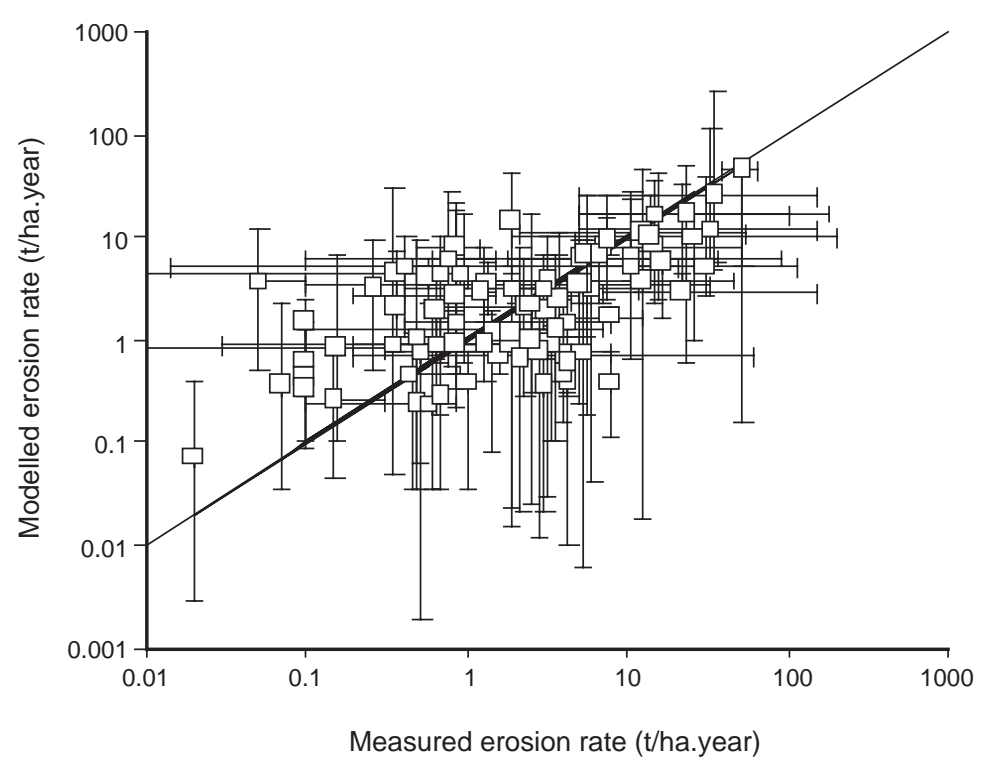

Fig. 7. The comparison between predicted mean annual and measured average erosion rates for 83 locations. The lowest (lower and left bars) and largest values (upper and right bars) are also shown for both predicted and measured rates. The $R^{2}$ is 0.64 and standard error is $3.84 \mathrm{t} /$ ha.year. The $1: 1$ line is shown.

Table 2. Estimated soil loss rates and rates of erosion acceleration since European settlement from major land use categories

\begin{tabular}{lcccc}
\hline Landuse group & $\begin{array}{c}\text { Approx. total } \\
\text { area } \\
\left(\mathrm{km}^{2} \times 10^{3}\right)\end{array}$ & $\begin{array}{c}\text { Total } \\
\text { erosion } \\
(\mathrm{Mt} / \mathrm{year})\end{array}$ & $\begin{array}{c}\text { Av. erosion rate } \\
(\mathrm{t} / \text { ha.year })\end{array}$ & $\begin{array}{c}\text { Rate of acceleration } \\
\text { (ratio of current to } \\
\text { natural rates })\end{array}$ \\
\hline Forest & 277 & 26 & 1.0 & 1 \\
Woodland & 2180 & 726 & 2.8 & 1 \\
National park & 184 & 129 & 7.4 & 1 \\
Residual/native pastures & 4232 & 2304 & 5.4 & 3 \\
Plantation & 146 & 17 & 2.1 & 4 \\
Improved pastures/legumes & 200 & 19 & 1.1 & 5 \\
Cereals excluding rice & 193 & 63 & 2.7 & 18 \\
Oilseeds & 4 & 2 & 3.2 & 30 \\
Other agricultural lands & 16 & 26 & 11.1 & 33 \\
Sugarcane & 5 & 10 & 16.1 & 33 \\
\hline
\end{tabular}

permanent native pastures. Both predictions and observations suggest that, of the land uses large enough to list separately, sugar cane has the highest erosion rate. This is mainly because sugar cane is the most intensive land use in tropical areas where rainfall intensity is high. The observed rates on average for canelands are higher because of the predominance of measurements under the now largely superseded practice of annual tillage. The predicted average erosion rates for cereals are relatively low because cereal fields are often located in lands of low gradient and only moderate rainfall intensity. The observations (Fig. 8 and Table 1) show that rates are higher in the Darling Downs than in the lower rainfall intensity areas further south. 


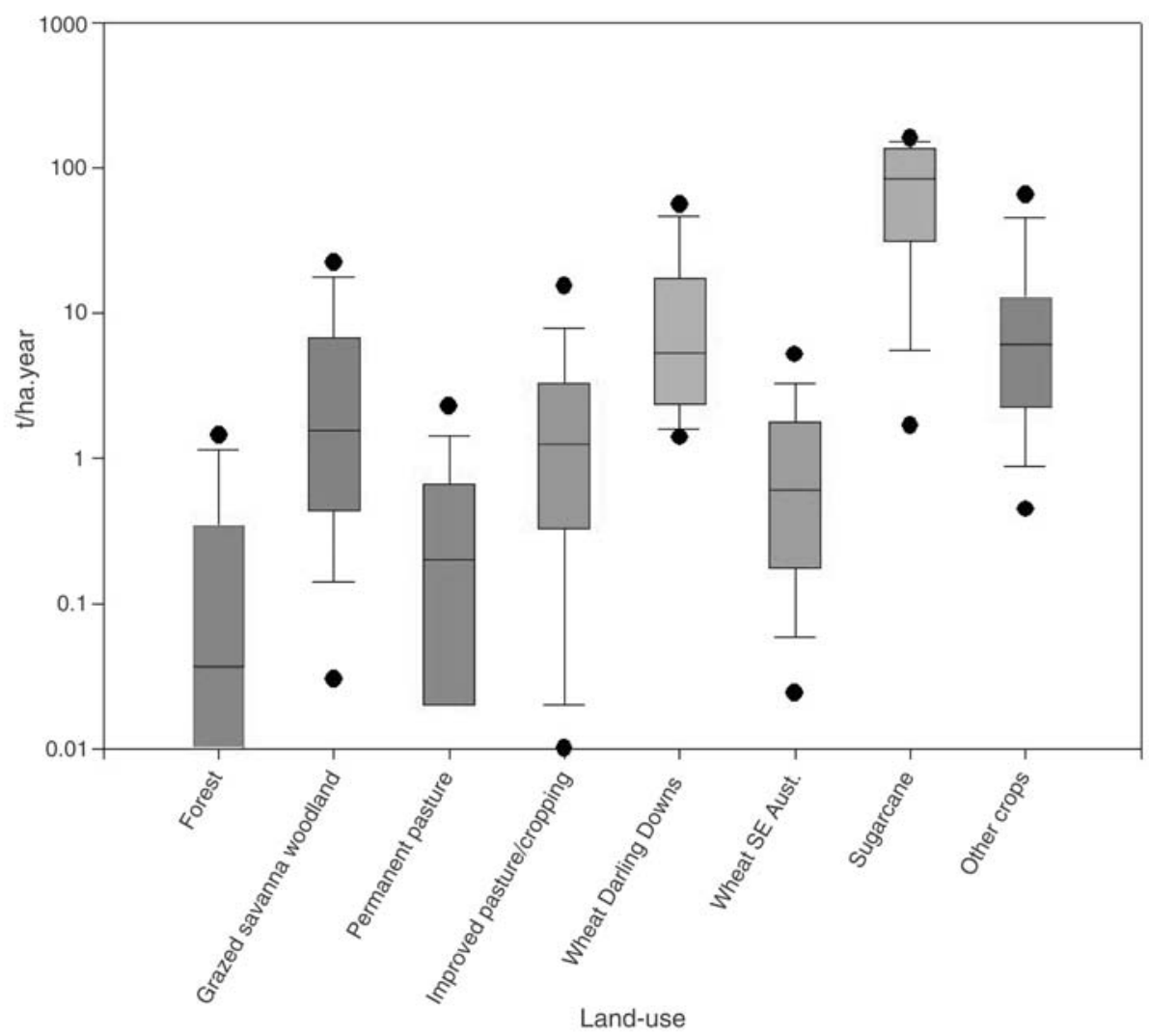

Fig. 8. Box-plot of erosion rate measured by a number of field measurements (listed in Table 1) against major land use groups. Cropping lands in the Darling Downs region, south-east Australia and canelands in the tropical areas as separate groups. For each land use group, the upper and lower dots represent two extreme values in the measurements. The lowest and highest lines represent the adjacent lowest and highest values and the three lines that form the box represent $25 \%$ percentile, $50 \%$ (median), and $75 \%$ percentile of values in the data, respectively.

In the north part of the country, cropping lands of high erosion hazard are more restricted in spatial extent but can cause local problems and will be significant in relatively small catchments dominated by intensive cropping activities. On average the predicted erosion rates in cropping lands are 5-30 times greater than the predicted rates for natural cover on those lands. The predicted soil loss rates for cropping land are less than those estimated in USA (Magleby et al. 1995) and in China (Li 1997) and some other tropical and subtropical countries. However, they are greater than the soil formation rates due to the generally low soil formation rate in Australia. It has been found that soil formation rates in Australia are below $0.5 \mathrm{t} /$ ha.year in eastern regions and effectively zero in most of other areas (Edwards 1988) compared with over $5 \mathrm{t} / \mathrm{ha}$.year in the USA (Magleby et al. 1995). Therefore, the current soil loss rate for agricultural lands will decrease the productivity of soil and eventually reduce the availability of arable soil for future generations.

Forests are predicted and observed to have the lowest erosion rates. Predictions are larger than observations because of the bias towards southern Australia in the measurements, but some over-estimation in the predictions was also identified. Erosion rates are significantly 


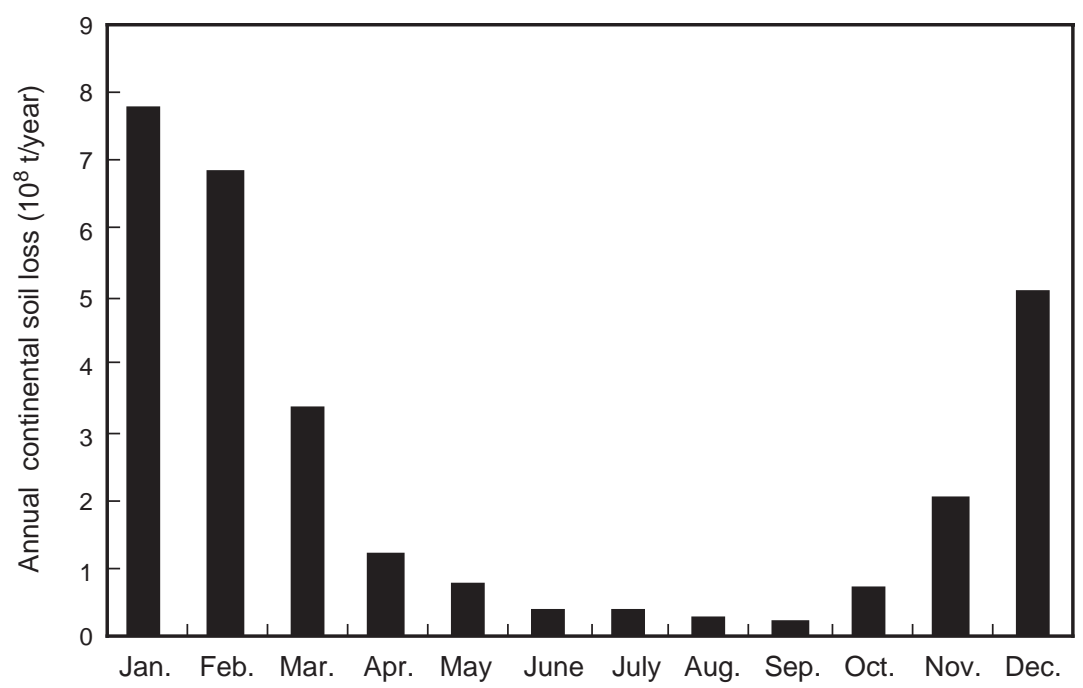

Fig. 9. The predicted monthly distribution of total soil loss across Australia.

higher in National Parks. This is primarily because most National Parks are located in the north part of the country, where the rainfall intensity is high, or in the arid inland, where there is little vegetation cover. These are the natural conditions in steep lands experiencing high intensity rainfall, and do not represent accelerated soil erosion rates.

Figure 9 shows the monthly distribution of total soil loss. It is found that over $90 \%$ of the erosion occurs in the summer period (from November to April). This summer dominant erosion pattern is clearly shown in Fig. 4 especially for tropical Australia, which is mainly a result of the intensive summer monsoon rainfall. However, the high erosion zone detected within the east part of the Murray-Darling Basin is one of weaker summer dominance.

\section{Discussion and conclusions}

Based on recently available spatial data on topography, rainfall, soil properties, land use, and time series analysis of remotely sensed data, a continental map of sheetwash and rill erosion has been derived for both current and pre-European settlement vegetation cover. The RUSLE was applied on a monthly averaged basis, calculating appropriate erosivity and cover factors for each month, to represent the erosive potential of rainfall and runoff for each temporally distinct period. The slope length and steepness factors were estimated by topographic scaling using high resolution DEMs. The resulting $0.01^{\circ}$ resolution digital maps of sheetwash and rill erosion and its monthly distribution can be used for assessing regional erosion hazard, determining the seasonal timing of erosion hazard, and, most importantly, prioritising natural resource management to reduce erosion.

The broad predicted sheetwash and rill erosion patterns are consistent with plot data gathered from the literature. It is predicted that sheetwash and rill erosion increases from south to north, which is mainly a result of the continental scale rainfall erosivity distribution and seasonally low vegetation cover in the north. Locally, slope steepness and land use are the major factors responsible for the variation of erosion rates. Seasonally, the erosion rate is greater in summer for most of the continent, especially for the tropics, which also follows the broad-scale climatic trend. Regions such as Tasmania and south-west Western Australia 
are predicted to have low soil erosion rates, largely a result of low rainfall intensity at times of low cover. Most of the predicted patterns are supported by the available field data listed in Table 1. The modelled results have the advantage of predicting rates across the full range of conditions experienced, compensating for biases in the geographical distribution of the field data.

The acceleration of erosion under current land use was studied by modelling the pre-settlement sheetwash and rill erosion rate using an interpolation of natural cover from reserves and other minimally disturbed areas. The results show that although the current erosion rates of cropping lands are not high compared with some land use groups, the rates are 5-30 times higher than the predicted natural vegetation cover for the same location on average. It provides essential information for the assessment of land use impact in terms of possible environmental degradation and pollution of both land and water resources.

The predictions for cropping lands can be improved by specifying tillage types, crop rotation, contour cultivation, and contour bank management for agricultural lands. For pasture lands, improvement can be achieved by using grazing pressure information. For the steeper and more arid areas predictions could be improved by incorporating the effect of significant cover of rocks and gravels rather than erodible soil. The results could be improved by combining surface rock cover and the estimated vegetation cover to estimate the $C$-factor. Information about percentage surface rock cover could be estimated by analyses of soil survey data.

Soil erosion is naturally highly variable. This needs to be recognised when comparing current rates of erosion from one place to another and when the erosion control policies are set. It should be expressed in relation to spatially varying benchmarks, such as natural erosion rates, that recognise the inherent landscape variability, rather than referring to absolute rates alone or using a single benchmark applied across diverse landscapes.

Inevitably, uncertainties exist in the erosion maps presented in this study. The uncertainties were introduced by spatial input data sets in the first place and by combining those input data at different spatial and temporal resolutions during the modelling processes. There is an urgent need to develop new methods for uncertainty analysis based on sparse measurements and noisy spatial data.

There are some possible dangers of misusing the erosion maps presented in this study. Firstly, the broad-scale information we presented here cannot be used to make decisions at small scales, such as pixel or sub-pixel level. Soil erosion information at finer scale can only be estimated appropriately using higher resolution inputs or direct measurements. Secondly, large differences in rates are possible when compared with event-based observations. Finally and most importantly, the soil loss rates predicted in this study represent annual averaged soil erosion generated within each $1-\mathrm{km}$ pixel treated in isolation. The digital erosion maps give a first approximation of the likely sediment sources but do not indicate sediment yields from the catchments. Sediment yields from hillslopes or small catchments are often about an order of magnitude lower than the hillslope erosion rates (Edwards 1993; Wasson 1994) as most of the sediment travels only a short distance (Parsons and Stromberg 1998), and is deposited before getting into the streams. At broad scale, those processes are often represented by a scaling factor, known as a sediment delivery ratio (SDR), which is out of the scope of the present paper but was dealt with by the authors in other studies (Lu et al. 2003a). The continental sheetwash and rill erosion maps have been used, with consideration of SDR and other inputs to account for other erosion types (e.g. gully and stream bank erosion), to predict river sediment loads across the more intensely used part of the Australian continent (Prosser et al. 2001). 


\section{Acknowledgments}

The research was supported by the National Land and Water Resource Audit, Australia and benefited from the partnerships between CSIRO Land and Water and State agencies. Thanks to Drs Elisabeth Bui and Neil McKenzie for useful discussions about $K$-factor estimation using ASRIS soil attributes. We are also grateful to two anonymous referees whose comments significantly improved the paper.

\section{References}

Atkinson G (1984) Soil erosion following wildfire in a sandstone catchment. National Soils Conference. (ASSSI: Brisbane, Q1d)

Blong RJ, Riley SJ, Crozier PJ (1982) Sediment yield from runoff plots following bushfire near Narrabeen Lagoon, NSW, Search 13, 36-38.

BRS (2002) Land use mapping at catchment scale: Principles, procedures and definitions. Bureau of Rural Sciences, Canberra.

Capelin MA, Truong PN (1985) Soil erosion within pineapple fields in SE Queensland. In 'Proceedings of the 4th Australian Soil Conservation Conference'. Maroochydore, Qld. pp. 220-221.

Carlile P, Bui E, Moran CJ, Minasny B, McBratney AB (2001a) Estimating soil particle size distributions and percent sand, silt and clay for six texture classes using the Australian Soil Resource Information System point database. Technical Report 29/01, CSIRO Land and Water, Canberra.

Carlile P, Bui E, Moran CJ, Simon D, Henderson B (2001b) Method used to generate soil attribute surfaces for the Australian Soil Resource Information System using soil maps and look-up tables. Technical Report 24/01, CSIRO Land and Water, Canberra.

Ciesiolka CA (1987) Catchment management in the Nogoa watershed. Australian Water Research Community, Research Project 80/128, Department of Resources and Energy.

Ciesiolka CA, Coughlan KJ, Rose CW, Escalante MC, Mohd.Hashim G, Paningbatan Jr EP, Sombatpanit S (1995) Methodology for a multi-country study of soil erosion management. Soil Technology 8, 179-192.

Croke J, Hairsine PB, Fogarty P (1999) Sediment transport, redistribution and storage on logged hillslopes in south-eastern Australia. Hydrological Processes 13, 2705-2720.

Cullen P (1995) Land degradation on the Central Plateau, Tasmania. Occasional Paper No. 34, Tasmanian Parks and Wildlife Service, Hobart.

De Gruijter JJ, McBratney AB (1988) A modified fuzzy k means for predictive classification. In 'Classification and related methods of data analysis'. (Ed. HH Bock) pp. 97-104. (Elsevier Science: Amsterdam)

Edwards K (1987) Runoff and soil loss studies in New South Wales. Technical Handbook No. 10, Soil Conservation Service of NSW, Sydney, NSW.

Edwards K (1988) How much soil loss is acceptable? Search 19, 136-140.

Edwards K (1993) Soil erosion and conservation in Australia. In 'World soil erosion and conservation'. (Ed. D Pimentel) pp. 147-169. (Cambridge University Press: Cambridge)

Edwards K, Zierholz C (2001) Soil formation and erosion rates. In 'Soils: Their Properties and Management'. (Eds PEV Charman, BW Murphy) pp. 39-58. 2nd edn (Oxford University Press: Oxford)

Elliott GL, Dight DCG (1986) An Evaluation of the surface stability of rehabilitated overburden in the upper hunter valley, NSW. Report to NSW Coal Association, Sydney, Australia.

Erskine WD, Mahmoudzadeh A, Browning C, Myers C (2003) Sediment yields and soil loss rates from different land uses on Triassic shales in Western Sydney, NSW. Australian Journal of Soil Research 41, $127-140$.

Erskine WD, Mahmoudzadeh A, Myers C (2002) Land use effects on sediment yields and soil loss rates in small basins of Triassic sandstone near Sydney, NSW, Australia. Catena 49, 271-287.

ESRI (2003) ESRI GIS software. http://www.esri.com/software/index.html. ESRI, Redlands, California.

Freebairn DM (1982) Soil erosion in perspective, In 'Division of Land Utilisation Technical News'. Vol 6, pp. 12-15. (Queensland Department of Primary Industry: Brisbane)

Freebairn DM, Loch RJ, Silburn DM (1996) Soil erosion and soil conservation for Vertisols. In 'Vertisols and technologies for their management'. (Eds N Ahmad, A Mermut) pp. 303-362. (Elsevier Publishing: Amsterdam)

Freebairn DM, Silburn DM, Loch RJ (1989) Evaluation of soil erosion models for clay soils. Australian Journal of Soil Research 27, 199-211. 
Freebairn DM, Wockner GH (1986) A study of soil erosion on Vertisols of the eastern Darling Downs, Queensland. II. The effect of soil, rainfall, and flow conditions on suspended sediment losses. Australian Journal of Soil Research 24, 159-172.

Gallant JC (2001) Topographic scaling for the NLWRA sediment project. Technical Report 27/01, CSIRO Land and Water, Canberra.

Graham OP (1988) Land degradation survey of NSW 1987-88: methodology. Technical Report No. 7, Soil Conservation Service of NSW.

Henderson B, Bui E, Moran CJ, Simon D, Carlile P (2001) ASRIS: Continental-scale soil property predictions from point data. Technical Report 28/01, CSIRO Land and Water, Canberra.

Humphreys GS, Mitchell PB (1983) A preliminary assessment of the role of bioturbation and rainwash on sandstone hillslopes in the Sydney Basin. In 'Aspects of Australian sandstone landscapes'. (Eds RW Young, GC Nanson) Australia and New Zealand Geomorphology Group Special Publication No. 1. (University of Wollongong: Wollongong, NSW)

Jeffrey SJ, Carter JO, Moodie KB, Beswick AR (2001) Using spatial interpolation to construct a comprehensive archive of Australian climate data. Environmental Modelling and Software 16, 309-330.

Kinnell PIA (1983) The effect of kinetic energy of excess rainfall on soil loss from non-vegetated plots. Australian Journal of Soil Research 21, 445-453.

Lang RD, McCaffery LAH (1984) Ground cover ñ its affects on soil loss from grazed runoff plots, Gunnedah. Journal of Soil Conservation Service of NSW 40, 56-61.

Li X (1997) Driving forces of arable land conversion in China. IR-97-076, International Institute for Applied Systems Analysis, Laxenburg, Austria. p.24.

Loch RJ, Rosewell CJ (1992) Laboratory methods for measurement of soil erodibility ( $K$ factors) for the Universal Soil Loss Equation. Australian Journal of Soil Research 30, 233-248.

Loch RJ, Slater BK, Devoil C (1998) Soil erodibility $(\mathrm{Km})$ values for some Australian soils. Australian Journal of Soil Research 36, 1045-1055.

Loughran RJ, Elliott GL (1996) Rates of soil erosion in Australia determined by the Caesium-137 technique: a national reconnaissance survey. IAHS Publication 236, 275-282.

$\mathrm{Lu}$ H, Moran CJ, Prosser IP (2003a) Modelling sediment delivery ratio over the Murray Darling Basin: hydrologic control and spatial-temporal interaction. In 'Proceedings of MODSIM 2003'. Townsville. (Ed. D Post) pp. 485-491.

Lu H, Raupach MR, McVicar TR, Barrett DJ (2003b) Decomposition of vegetation cover into woody and herbaceous components using AVHRR NDVI time series. Remote Sensing of Environment 86, 1-18.

$\mathrm{Lu} \mathrm{H}, \mathrm{Yu} \mathrm{B}(2002)$ Spatial and seasonal distribution of rainfall erosivity in Australia. Australian Journal of Soil Research 40, 877-901.

Magleby R, Sandretto C, Crosswhite W, Osborn CT (1995) Soil erosion and conservation in the United States: an overview. AIB-718. Economic Research Service, US Department of Agriculture. p.29.

Mahmoudzadeh A, Erskine WD, Myers C (2002) Sediment yields and soil loss rates from native forest, pasture and cultivated land in the Bathurst area, NSW. Australian Forestry 65, 73-80.

McFarlane DJ, George RJ, Loughran RJ, Elliott GL, Ryder AT, Bennett D, Tille PJ (2000) A national reconnaissance survey of soil erosion: Australia - Western Australia. A report for the Australian National Landcare Program, Department of Primary Industries and Energy. The University of Newcastle, NSW, Australia, 220pp.

McKenzie NJ, Jacquier DW, Ashton, LJ, Cresswell HP (2000) Estimation of soil properties using the Atlas of Australian Soils. Technical Report 11/00, CSIRO Land and Water, Canberra.

Neil DT, Fogarty P (1991) Land use and sediment yield on the Southern Tablelands of New South Wales. Australian Journal of Soil and Water Conservation 4, 33-39.

Neil DT, Galloway RW (1989) Estimation of sediment yields from catchments farm dam. Australian Journal of Soil and Water Conservation 2, 46-51.

Newcombe CP, MacDonald DD (1991) Effects of suspended sediments on aquatic ecosystems. North American Journal of Fisheries Management 11, 72-82.

NLWRA (2001) Australian agriculture assessment. National Land and Water Resources Audit, Canberra.

Palis RG, Rose CW, Saffigna PG (1997) Soil erosion and nutrient loss IV. Effect of slope length on runoff, sediment yield, and total nitrogen loss from steep slopes in pineapple cultivation. Australian Journal of Soil Research 35, 891-905.

Parsons AJ, Stromberg SGL (1998) Experimental analysis of size and distance of travel of unconstrained particles in interrill flow. Water Resources Research 34, 2377-2381. 
Pimentel D, Harvey C, Resosudarmo P, Sinclair K, Kurz D, McNair M, Crist S, Shpritz L, Fitton L, Saffouri R, Blair R (1995) Environmental and economic costs of soil erosion and conservation benefits. Science 267, 1117-1123.

Prosser IP, Rustomji P, Young WJ, Moran C, Hughes A (2001) Constructing river basin sediment budgets for the National Land and Water Resources Audit. Technical Report 15/01, CSIRO Land and Water, Canberra.

Prove BG, Doogan VJ, Truong PNV (1995) Nature and magnitude of soil erosion in sugarcane land on the wet tropical coast of north-eastern Queensland. Australian Journal of Experimental Agriculture 35, 641-649.

QSC (1997) Sugar note. Queensland Sugar Corporation. p. 84.

Raupach MR, Kirby JM, Briggs PR, Barrett DJ (2001) Balances of water, carbon, nitrogen and phosphorus in Australian landscapes: (1) Project description and results. Technical Report 40/01, CSIRO Land and Water, Canberra.

Renard KG, Foster GA, Weesies DK, McCool DK, Yoder DC (1997) 'Predicting soil erosion by water: A guide to conservation planning with the Revised Universal Soil Loss Equation.' Agriculture Handbook 703. (United States Department of Agriculture: Washington, DC)

Rosewell CJ (1986) Evaluation of the universal soil loss equation-bare fallow plot experiments. Report SCS, Sydney, Australia.

Rosewell CJ (1993) 'SOILOSS - A program to assist in the selection of management practices to reduce erosion.' Technical Handbook No.11. (Soil Conservation Service of New South Wales: Sydney)

Rosewell CJ (1997) Potential source of sediments and nutrients: Sheet and rill erosion and phosphorus sources. Australia: State of the Environment Technical Paper Series (Inland Waters), Department of the Environment, Sport and Territories, Canberra.

Rulequest Research (2001) Rulequest Research Data Mining Tools. http://rulequest.com.

Rutherfurd ID, Ladson A, Tilleard J, Stewardson M, Ewing S, Brierley G, Fryirs K (1998) Research and development needs for river restoration in Australia. LWRRDC Occasional Paper No. 15/98, NSW.

Sallaway MM (1979) Soil erosion studies in the Mackay district. In 'Proceedings of the Australian Society Sugar Cane Technologist Conference’. (Ed. BT Egan) pp. 125-133. (Watson Ferguson and Co: Brisbane)

Wallbrink PJ, Roddy BP, Olley JM (2002) A tracer budget quantifying soil redistribution on hillslopes after forest harvesting. Catena 47, 179-201.

Wasson RJ, Olive LJ, Rosewell CJ (1996) Rates of erosion and sediment transport in Australia. IAHS Publication 236, 139-148.

Williams MAJ (1973) The efficacy of creep and slopewash in tropical and temperate Australia. Australian Geographical Studies 11, 62-68.

Wischmeier WH, Johnson CB, Cross BV (1971) A soil erodibility nomograph for farmland and construction sites. Journal of Soil and Water Conservation 26, 189-183.

Wischmeier WH, Smith DD (1978) 'Predicting rainfall erosion losses: A guide to conservation planning.' Agriculture Handbook No. 537. (US Department of Agriculture: Washington, DC)

Yu B, Ciesiolka CA, Rose CW, Coughlan KJ (2000) A validation test of WEPP to predict runoff and soil loss from a pineapple farm on a sandy soil in subtropical Queensland, Australia. Australian Journal of Soil Research 38, 537-554.

Yu B, Rosewell CJ (1996) An assessment of a daily rainfall erosivity model for New South Wales. Australian Journal of Soil Research 34, 139-152.

Manuscript received 23 December 2002, accepted 29 May 2003 